\title{
The Accidental Clinician and the Experienced Director: A Conversation on the Value of Externships
}

\author{
Marjorie A. Silver \\ Touro Law Center, msilver@tourolaw.edu \\ Mary Jo Eyster
}

Follow this and additional works at: https://digitalcommons.tourolaw.edu/scholarlyworks

Part of the Legal Education Commons, and the Legal Profession Commons

\section{Recommended Citation}

Silver, Marjorie A. and Eyster, Mary Jo, "The Accidental Clinician and the Experienced Director: A Conversation on the Value of Externships" (2010). Scholarly Works. 622.

https://digitalcommons.tourolaw.edu/scholarlyworks/622

This Article is brought to you for free and open access by the Faculty Scholarship at Digital Commons @ Touro Law Center. It has been accepted for inclusion in Scholarly Works by an authorized administrator of Digital Commons @ Touro Law Center. For more information, please contact Iross@tourolaw.edu. 


\title{
The Accidental Clinician and the Experienced Director: A Conversation on the Value of Externships
}

\author{
Mary Jo Eyster* \\ Marjorie A. Silver \\ PREFACE
}

In the summer of 2010, Mary Jo Eyster and Marjorie Silver conversed, via email, about the ways in which externship programs add unique value to the student's education, separate and apart from their cost-effectiveness as compared to the in-house clinic. The result is this paper. Over the course of their exchange, they talk about many things and, as things often go, their conversation doesn't always follow a linear path. Marjorie explains how she came to be an externship seminar teacher, and why she invited Mary Jo to engage in this project, and Mary Jo explain why she agreed. They discuss what we mean when we talk about externships (Introduction); and Mary Jo offers some context in the form of a brief history of the clinical education movement, and where externships fit within that history. Why, for example, did the $A B A$ regulate externships far more closely than in-house clinical programs, and on what assumptions and, perhaps, misperceptions about what happens in the well-designed externship were such decisions based? (Part I).

Mary Jo and Marjorie agree that the well-designed, well-executed program should drive the design, teaching and administration of externships and their accompanying seminars. They share the goals that each of them privilege in the programs they have designed, and explore the challenges and opportunities presented by placing students in real law offices, both public and private. They discuss how they help students negotiate the balance between work and life, and expose them to alternative career choices so that their students may find careers congruent with their core values. They explore how externships provide unparalleled opportunities for students to set their own learning goals and priorities, as well as opportunities to learn to work successfully with different, sometimes challenging, personalities. Above all, they explore how the well-designed externship program supports students in becoming self-reflective, selfcorrecting learners and practitioners (Part II). They agree that students benefit most by having multiple and varied experiential learning opportunities that include externships, in-house clinics, as well as the hybrid forms that have emerged in recent years. Each of these offers important learning opportunities in the transformation of law students into independent practitioners. And while the realities are such that externships will remain the most cost-effective method for providing authentic practical experience within the curriculum, what they offer is so much more

\footnotetext{
* Adjunct Associate Clinical Professor, Brooklyn Law School.

*** Professor of Law, Touro Law Center. Both Mary Jo and I want to extend our great appreciation for the excellent research assistance we received from Mark Guarriello and Katharine O'Dette in writing this paper-we truly couldn't have done it without them! Thanks, too, to the Touro Law Librarians. A Touro Law Center summer research grant helped support my work on this paper.
} 
than just less expensive alternatives to these other models. All of us who value experiential learning should join together to oppose efforts afoot to devalue clinical offerings, regardless of their form (Part III \& Conclusion).

\section{Introduction}

\section{Marjorie:}

So, Mary Jo, I thought it made sense to begin by explaining why I invited you to do this paper with me. I'll start with how it came to pass that I became an externship seminar teacher.

For more than a quarter of a century, I have been a traditional tenure-track, then tenured, classroom teacher at two different law schools. My primary teaching areas are, and have been virtually through all of that, Civil Procedure and Professional Responsibility.

Due to friendships that predated my teaching career, I have long hung around some of 'the most dynamic and thoughtful clinical teachers in the country. I have often heard, over expensive dinners with lots of wine, that no experiential learning can hold a candle to welldesigned law clinics: not externships, and certainly not simulation courses. Although my instincts and knowledge of the programs at Touro suggested otherwise, I was in a rather lame position to argue, unfamiliar as I was with the theory and practice of clinical legal education generally-or with that of externships in particular. ${ }^{1}$

In 1998, I fell in with another "outsider" group of legal educators and lawyers: those affiliated with what is known as Therapeutic Jurisprudence ("TJ"). This relationship informed the future of my scholarly interests, which have since focused loosely on the importance of psychological-mindedness and emotional competence to good lawyering. This has led me to explore what lawyers need to know and what law schools need to teach to fill what I have come to believe are core competencies. In 1999, I published my first article on this subject in the Clinical Law Review (an accomplishment of which I was most proud!), ${ }^{2}$ and soon thereafter, David Wexler and Bruce Winick asked my permission to include it in their 2000 anthology, Practicing Therapeutic Jurisprudence: Law as a Helping Profession ("Practicing TJ"). And I continued to write on TJ-related subjects and speak internationally at TJ-affiliated conferences.

\footnotetext{
${ }^{1}$ I knew a little bit more about simulations, having used them in my own teaching for decades, but the only comparisons I could offer were with other doctrinal classes that did not use similar active learning techniques.

${ }^{2}$ Marjorie A. Silver, Love, Hate and Other Emotional Interference in the Lawyer/Client Relationship, 6 CLINICAL L. REV. 259 (1999) (hereinafter Love \& Hate).
} 
In spring 2005, I was able to offer a seminar entitled, Selected Topics in Professional Responsibility: Lawyering as a Happy, Healthy, Healing and Ethical Profession. ${ }^{3}$ Practicing TJ was one of the principal texts ${ }^{4}$ supplemented by numerous articles largely on alternative ways to practice law, aimed at enhancing both lawyers' and clients' wellbeing. Only four students enrolled, but luckily I was allowed to teach the seminar nonetheless, and the five of us had a truly glorious semester exploring this emerging field of inquiry.

More than happy with the first experience, I was gladdened to be allowed to offer the seminar the following spring as well, following a sabbatical to work on my book, The Affective Assistance of Counsel: Practicing Law as a Healing Profession. ${ }^{5}$ This time, no students enrolled! After I picked my ego up off the floor, I realized that I was fighting more than an uphill battle. Our students were overwhelmed with required courses, distribution requirements, and other core courses needed for the bar exam. Happy \& Healthy had little if any traction against such odds.

At that time, the seminar component of Touro's externship practicum was usually taught by adjuncts or random faculty whose classes had been cancelled for under-enrollment. I quickly came to realize, however, that I could teach virtually the same Happy \& Healthy course in context, through teaching the externship seminar. I ran this idea by my colleague and friend, Marianne Artusio, who at that time directed both programs, and she welcomed having a fulltime faculty member committed to teaching the seminar on an ongoing basis. The dean agreed and so, in the fall of 2006, I began what has come to account for a quarter of my annual case load, the externship seminar. ${ }^{6}$

By this time, my book was in page proofs, and I assigned it as one of two required texts. The other was the one and only text created specifically for externship programs, Learning from Practice which I affectionately call "OWL". ${ }^{7}$

I pretty much knew which chapters from my book I was interested in covering, and I planned, as I had done with the predecessor seminar, to offer the students choice on a critical

\footnotetext{
${ }^{3}$ The seminar name is a take-off on Patrick Schiltz, On Being a Happy, Healthy, and Ethical Member of an Unhappy, Unhealthy, and Unethical Profession, 52 VAND. L. REV. 871 (1999). This article, which I assign to my seminar students, is a sober look at the realities of big firm practice (and that is an understatement).

4 Dennis P. Stolle, David B. Wexler, Bruce J. Winick, Practicing Therapeutic Jurisprudence: Law as a HelPing Profession 5 (paperback 2000). The other texts were CARL HoRn III, LAWYERLIFE: FINDING A LIFE AND A Higher Calling in the Practice of Law (paperback 2003) and Steven KeEva, Transforming Practices: FINDING JOY AND SATISFACTION IN THE LEGAL LIFE (paperback 1999).

5 The Affective Assistance of Counsel: Practicing Law as a Healing Profession (Marjorie A. Silver, ed. 2007).

${ }^{6}$ Generally, in the fall and spring, I also teach Civil Dispute Resolution and Procedure (CDR\&P) I, and in the spring I teach CDR\&P II and Professional Responsibility.

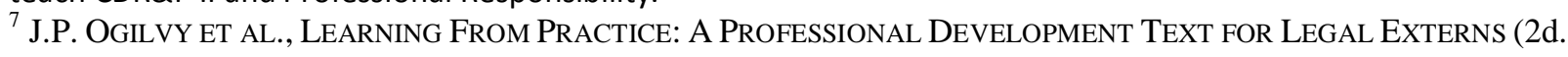
ed. 2007). The first edition was published in 1998.
} 
amount of the subject matter. ${ }^{8}$ I realized, however, that I couldn't and shouldn't ignore what the students were experiencing at their individual placements. In this respect, OWL was a godsend. I learned so much from these wise and experienced authors. Although much of their wisdom I knew intuitively, I had never focused on how one communicates such skills as assignment clarification and effective feedback, which I soon learned would be essential in order for my students to maximize the benefits of their placement experience. I also had never thought about the opportunities that externships presented for empowering students to formulate their own learning goals.

And I learned "on the job" as well. I followed my instincts, often out of self-preservation, and, for the most part, they served me quite well. For example, the seminar is scheduled-as are all of Touro's clinical seminars - to meet for one three-hour block once a week. How on earth was I to fill three hours, when two often felt like an endurance exam? I soon decided to invite guests each week to speak for one of those hours. Over the past several years, I have built up a slate of (mostly) attorneys, whom I ask to share with the students how they got from where the students are now (in their last year of law school), to where the guest is now, what they like about their work, what they don't like so much, and what their work/life balance is like. The students love these visits, which serve multiple purposes, not the least of which is to expand the students' awareness of a far greater variety of practice settings and possibilities for their future careers. ${ }^{9}$

I have a lot more to say about the seminar, what makes it work so well and why. In many ways, it has been my most successful teaching experience. But for now, let me just say, Mary Jo, that I am so glad you accepted my invitation to co-author this paper with me. To a significant degree, I am an accidental clinician. You, however, have decades of experience in both traditional in-house clinics and multiple externship programs, and I welcome the opportunity to converse with you about how each complements the other.

Perhaps you might want to begin by explaining why you decided to accept my invitation?

\section{Mary Jo:}

I'm glad I accepted your invitation too. This has been a wonderful learning experience for me. I have a tendency to go off on tangents, which is what I'm about to do, so give me a bit of time and I will work my way into answering your question. Although I am not an "accidental" clinician, I didn't start out as an externship teacher. I began teaching an in-house litigation clinic in 1984, and continued to teach that clinic for about 6 years. I was attracted to the idea of the externship clinic because of the wealth of opportunities for students in the New York City region. I really enjoyed in-house clinical teaching, but it was troubling that so few of our

\footnotetext{
${ }^{8}$ Michael H. Schwartz, et al, Teaching Law By Design: Engaging Students from the Syllabus to the Final Exam 9 (2009) (describing importance of giving adult learn3ers some role "in deciding what and how they will learn.")

${ }^{9}$ See infra text at note [].
} 
students were able to enroll in our in-house clinics. At the time, in the early 1990s, Brooklyn Law had an extensive clinical program, both in-house and externships. But even with a number of in-house clinics, a relatively small percentage of our students were able to enroll. The law school had three externship clinics, named at the time the Civil, Criminal and Judicial Clinics. The Civil Clinic was the one that I took over in about 1991; it was then, and remains today, the largest and most amorphous. Having so many opportunities for students to experience different types of practice settings and areas of substantive law was a real appeal. At the same time, this meant that there were going to be challenges in creating a workable structure. Let me digress, because I think some background is needed.

Often it is unclear to me, and I assume to others as well, what we are talking about when we talk about externships. I use the terms externship, externship clinic, internship and field placement clinic interchangeably, to signify a particular type of clinical experience. However, I recognize that there are not bright lines (there are fuzzy lines) to separate this type of clinical experience from the in-house model of clinical education. The externship clinic in my parlance has a feature that is essential: the student is working in a law office, under the supervision of an attorney, whose primary role is attorney, rather than faculty member. ${ }^{10}$

Within this definition is much room for variation. In some instances the attorney supervisor, may be an adjunct professor at the law school where the students are enrolled. The supervisor might not be an adjunct, but might have developed a program within that office, in cooperation with the law school, in which several students are placed to provide service to the client base, with the supervisor providing direct on site supervision, feedback and guidance. In some instances the field supervisor might also provide workshops, training, or even teach a regular seminar as part of the placement. ${ }^{11}$ Another variation within this model is that a full time faculty member might teach, or co-teach, the seminar. S/he might even take part in some aspects of the case supervision. In fact, this type of clinic structure has become more common in the past ten years. Some schools call this type of program either a hybrid, or even an in-house clinic. I know there are many programs that are taught by clinicians with solid "in-house" credentials (myself included), where the course has definite externship elements. And yet, these distinctions still absorb us.

A more standard externship model involves many students working in an array of practice settings, each student assigned to one (or more) supervisors within one of the placement offices. The faculty member who directs the externship course either teaches a regular seminar or provides some other form of oversight (electronic or distance communication, site visits, preplacement course training).

What the various models have in common are, I think, the following:

\footnotetext{
${ }^{10}$ Margaret Martin Barry, Jon Dubin, and Peter Joy, Clinical Education for the Millennium: The Third Wave, 7 CLIN L. Rev, 1 (2000); REPORT OF THE ASSOCIATION OF AMERICAN LAW SCHOOLS - AMERICAN BAR AsSOCIATION COMMiTTEE ON GUIDELINES FOR CLINICAL LEGAl EDUCATION, 133 - 167 (1980) [hereinafter, “Guidelines”]. ${ }^{11}$ Guidelines, supra, at $9-10$.
} 
1. The supervisor's primary responsibility is to the client or the agency, office or court by which s/he is employed. Regardless of the level of skill and commitment to the supervision and teaching role, the lawyer role is primary.

2. The supervisor may or may not be compensated, but does not have a "secure" employment relationship with the academic institution.

3. The experience the student receives in the placement will usually be based on office and client needs, and not necessarily designed to meet specific pedagogical goals.

What are some of the many reasons that externship clinics are popular? Cynics might look at the low cost, but in many programs' designs that is not really the case. ${ }^{12}$ Instead, I believe there are a number of important reasons that students, law teachers and practitioners (including prospective employers) find the externship clinic an appealing addendum to the law school curriculum.

Externships are real, or rather, the experience in the externship is real. Students are eager to learn about the real world of practice, and that world is just across the street in the law offices, courts, agencies and corporations surrounding the law school. It is probably time for the academy to acknowledge that the majority of our students are in law school because they hope to practice law. Some may hope to write law review articles, to teach, to engage in law reform. But many of them (dare I say most?) want to practice law. ${ }^{13}$ Law school courses, on the whole, don't give students any insight into the practice of law. Externships plunge them directly into the world of practice. ${ }^{14}$

Externships are valued because students believe that they will learn more about how stuff works than they do in the classroom. For many learners this is absolutely true. Learning theory (both adult learning theory and more general learning theory) is evolving toward the recognition that people do not all learn in the same way, and that many people do not learn as well by engaging in theoretical discussions as by engaging in the actual hands on experience of the

\footnotetext{
12 There is no question that, on the whole, the costs of externship clinics can be much lower than other clinical courses, and even other non-clinical courses. More on this later. See GuIDELINES, supra note (8).

13 Mary Jo: I have never conducted a formal survey to determine whether this is true. Perhaps because I am a clinical teacher, and have been for all of my twenty six years of teaching, these are the students I have been in contact with. In my past semester of teaching, I had approximately 200 students enrolled in the externship and inhouse clinics that I teach. These were not the only clinical programs offered at Brooklyn Law School, so there were certainly many more students who were enrolled in some type of clinic. These are the students I think of in making the statement about the desire to practice being more prominent than the desire to teach or write. Marjorie: This is undeniably true among students at schools like yours and ours, see SCHWARTZ, ET AL, supra note [8] at 32 ("The vast majority of our students plan to practice law and want to be good at it."); perhaps, not so at Yale, Harvard, or other top ten schools.

${ }^{14}$ A particularly insightful discussion of this phenomenon is contained in a speech by Donald A. Schon which was reproduced in part in the Clinical Law Review. See Donald A. Schon, Educating the Reflective Legal Practitioner" 2 CLIN. L. REV. 231, 233 - 37(1995) [hereinafter "Reflective Practitioner"].
} 
subject matter. ${ }^{15}$ Howard Gardner proposes a "school-community broker" as part of the educational structure of schools:

In my own view nothing is more important in a student's educational career than the encountering of a discipline or craft that fits a particular blend of intelligences - a pursuit worthy of a student's efforts for years or even a lifetime. Individuals of accomplishment often attribute enormous importance to 'crystallizing experiences' where they first confronted a pursuit that fit their learning strengths and styles. All too often, these matches occurred completely by chance.

"The goal of the school-community broker is to increase the likelihood that students will discover a vocational or avocational role that matches their own profile of intelligences. ..."16

In an externship learning experience, as in in-house clinics, the student is learning in a context that is broader than a course in Torts, Civil Procedure, Evidence and Con Law. Real clients walk in the door with un-labeled, undifferentiated problems, issues, concerns and desires. They want help, not an analysis of tort law.

The practice of law is exciting, and students derive energy and purpose from engaging with lawyers and clients in real life settings. Many of the students entered law school with some notion of the type of office and practice they wanted to pursue. Some might have had specific organizations or practice areas in mind. It is natural that they would be energized by the opportunity to obtain direct contact and experience in these settings.

Related to the foregoing, and admittedly not precisely a pedagogical consideration, is the notion of networking. There is undeniably a sense that one might make a strong, favorable impression on a prospective employer by spending a summer doing top quality work in the externship. The direct value of this is possibly over-rated, since most offices clearly do not hire most of the students who have been placed for credit. However, the possibility of either a direct connection, or at least a strong recommendation, is a factor.

One of the most compelling considerations favoring the externship learning experience is simply the wealth of opportunity. Especially in a major metropolitan area, where virtually every type of law practice setting is available within reasonable proximity, the diversity of practice settings is both a source of inspiration and a challenge.

For as long as I have been engaged in clinical education, there has been a clear and deep assumption about the relative value of external clinical experiences, as compared with in-house clinical experiences. Indeed, many clinical faculty members do not consider externship

15 See Thomas, Armstrong, Multiple Intelligences in the Classroom, 48 - 57(1994); Howard Gardner,

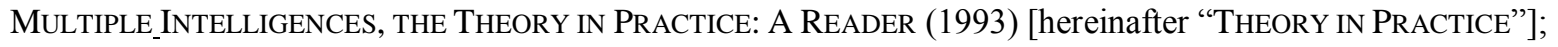
Reflective Practitioner, supra note (12), 240 - 44 and passim.

16 THEORY IN PRACTICE, supra, at $73-74$. 
programs "clinics," and are confused when I refer to my courses as external, or externship, clinics. The in-house clinic has long been considered the gold standard for clinical education, while external clinics have been relegated to, at best, grudging acceptance. Although this attitude has softened somewhat in more recent years, it is probably still the dominant belief among clinicians who enjoy full academic status. ${ }^{17}$

So, Marjorie, back to your question, after I guess what was a pretty long detour. Why was I intrigued by your invitation? I welcome the opportunity to discuss the attributes of sound pedagogy, and to share ideas about what programmatic features contribute to a quality learning experience. I hope that with open minds, legal educators can think more about the structure and content, and less about the label, in judging whether a course has value and validity. Maybe our conversation will help us, and some others, to discover some important lessons. Can we start with some basics about the background of clinical teaching?

\section{Marjorie:}

Great. Before we proceed, however, I just want to add a couple of thoughts on what you have written. While I completely agree that the placement supervisor's primary responsibility is to her client, and that the client drives the placement attorneys' agendas, the attorney who agrees to participate in our externship program takes on additional responsibilities. These responsibilities are pedagogical. As we shall explain in greater detail below, the student's goals and objectives, agreed to by the supervising attorney, should drive the student's experiences in the placement. But more on that later.

The second comment I want to make concerns what these externships are called. Touro, too, calls them externship clinics. Specifically, the official name of the one I teach is the Civil Externship Clinic. While what they are called is far less significant than what they contain, the background and context you offer in what follows helps set the stage for our discussion of the similarities and the differences between externships and in-house clinics, as well as their respective strengths and weaknesses.

\section{Part I}

\section{Clinical Methods, Clinical Programs, History and Politics}

\section{Mary Jo:}

What exactly is the essential difference between externship clinics and in-house clinics? I think it's useful to take a look at how these program structures differ, and how the differences might relate to the pedagogical value or legitimacy of each. In my effort to describe the different structures, I rely in large measure on the historic conceptions of in-house and externship clinics.

\footnotetext{
${ }^{17}$ For a general discussion of one view of the political forces surrounding this tension, see Stephen T. Maher, Clinical Legal Education in the Age of Unreason, 40 BufF. L. REv. 809 (1992) and Stephen T. Maher, The Praise of Folly: A Defense of Practice Supervision in Clinical Legal Education, 69 NEB. L. REv. 537 (1990).
} 
Over the past 20 years, as new models, the hybrids I mentioned earlier, have emerged, and as clinical pedagogy in both the externship and in-house arenas has developed, the differences are probably less clear, except at the ends of the spectrum. ${ }^{18}$

The in-house clinic is generally a program that is both supervised and taught (assuming one distinguishes between these two) by a faculty member. Typically there is relatively low student to faculty ratio (it used to be understood that an 8 to 1 ratio was standard; that ratio may no longer be the norm in most schools). ${ }^{19}$ In theory, the faculty member designs the curriculum, including the case selection, seminar content, assignments and supervision structure to achieve a pedagogical objective. ${ }^{20}$ The students are given primary responsibility for their clients and cases, while the faculty supervisor uses regular non-directive consultation to prompt the students to consider and decide each step in the representation process. Within this general description there are presumably innumerable variations, but the fundamental features - faculty supervision, low student-faculty ratios and student responsibility for case and client - are common to most inhouse clinics. $^{21}$

Externship clinics depart from this model most clearly in one respect. The students in the externship program are typically supervised by an attorney who is not a faculty member, and whose primary role is to represent the clients of her agency, firm or corporation. The student works with the supervisor on matters for which the supervisor has primary responsibility; the office in which the student is working generally retains the fundamental connection with the client. So it is usually, but certainly not always, true that the student does not have full responsibility for a case and a client. ${ }^{22}$ Beyond these basics, externship clinic models offer wide diversity. Some have very large enrollments, as do two that I have taught at Brooklyn Law School. Others may have enrollments that approximate the in-house clinic. Some externships are widely diverse in the types of placements, and practice venues, that can be included. Others are more narrowly focused on a particular area or type of practice. ${ }^{23}$

18 Margaret Martin Barry, Jon Dubin, and Peter Joy, Clinical Education for the Millennium: The Third Wave, 7 CLIN L. ReV, 1 (2000).

${ }^{19}$ RePort of the Committee on the Future of the In-House Clinic, 42 J. Legal. EduC. 508, 567 (1992) [hereinafter "FutURE OF THE IN-HOUSE CLINIC"].

${ }^{20} \mathrm{I}$ believe this theory is quite often not practiced in the actual design of clinical courses, whether in-house or externship. Rather, it seems that often courses are developed in response to the interests of a faculty member, the perception that there is a community need to be addressed, and/or the sense that an offering will be popular with students.

${ }^{21}$ FUTURE OF THE IN-HOUSE CLINIC, supra note 14, at 511 - 517.

${ }^{22}$ I think that in about 20 years of directing externships I have read over 10,000 student journals. It may not be the norm, but in many externships, students are given clients and cases, and not simply assignments.

${ }^{23}$ I have developed both of these models in my teaching. One with enormous diversity is the Civil Practice Internship Clinic, in which students may be placed in virtually any type of legal practice setting, excluding judicial and criminal offices. An external clinic with a very narrow focus is the Consumer Counseling Clinic, originally developed as an in-house program. In the externship model that I recently added, students are paired with bankruptcy practitioners who agree to take on pro-bono Chapter 7 bankruptcy clients, and to assign the students primary responsibility for those cases. 
Because the externship clinic case supervision is provided not by a faculty member, but by an attorney in practice, there is thought to be less accountability. Non-faculty supervisors might not always be as responsive to student supervision needs, and might assign tasks that have little pedagogical value to the student. Students might be less willing to raise these issues with an independent attorney because of concerns about job references. It is my understanding that these concerns are the essential justifications for devaluing the externship clinic as a legitimate learning experience. ${ }^{24}$

The ABA has gone to considerable lengths to regulate the structure of External Clinics, devoting Standard 305 (formerly Standard 306) to detailing the requirements of a field placement clinic. $^{25}$ There have been shifts in the specificity of the requirements, so that, for example, a "classroom component" has been either required or strongly preferred, either for all externship courses, or for those that award more than a specified number of credits (currently 4 , formerly 6). ${ }^{26}$ There is not a similar level of regulation for in-house clinics. Why the special treatment for externships?

Externship courses have been criticized as offering a job or placement experience, rather than a legitimate learning experience. Because there may be no guaranty, at least in the structure of some external clinics, that each student will receive quality legal work, clear guidance and ongoing evaluation, externships have been condemned as essentially cheap (both in terms of cost and in terms of quality) substitutes for "legitimate," i.e. in-house, clinical courses. That they are "cheaper" at least in terms of the cost to the law school is certain in most cases. Beyond that, the criticism is probably warranted in some, or even many cases, where the program structure lacks the features that would create an appropriate environment for experiential learning. There are undoubtedly many examples of "bad externships" where there is little thought to program design and goals, where students are given very little guidance about legitimate expectations, where supervision is insufficient or ineffective, and so on. ${ }^{27}$ However, the criticism of externship courses is often undifferentiated, and simply refuses to look honestly at how a program is designed. Understanding that there may be a variety of goals, and an array of methods for attaining those goals, is fundamental to the fair evaluation of any program. Let's focus on defining and discussing the well structured externship clinic. I believe that, not only is such a

${ }^{24}$ See Linda Morton, Creating a Classroom Component for Field Placement Programs: Enhancing Clinical Goals with Feminist Pedagogy, 45 ME. L. REV. 19, 23-33 (1993); Marc Stickgold, Exploring the Invisible Curriculum: Clinical Field Work in American Law Schools, 19 N.M. L. REV. 287 (1987).

25 Peter Joy, Evolution of ABA Standards Relating to Externships: Steps in the Right Direction?, 10 CLIN. L. REV. $681,693-707$ (2004).

26 See $i d$. at 717 - 721 (1993 and 2003 versions required contemporaneous seminars for programs awarding more than 6 academic credits); Standard 305 (e) (7) now requires some means of guided reflection to be contemporaneous for programs awarding 4 or more academic credits. 2009-2010 ABA STANDARDS FOR APPROVAL OF LAW SCHOOLS, Standard 305.

27 The growth of externship pedagogy, the increased collegiality of the externship teaching community, and five national externship conferences, probably deriving in part from the creation of the Clinical Legal Education Association which gave externship faculty a central, rather than marginal voice, has certainly helped to improve the standards and quality of externship programs. More on this later. 
course equal to, but in some cases it is better than, an in-house clinical experience for the achievement of some professional learning goals.

\section{Marjorie:}

I agree as well, and hope we can persuade our in-house clinical colleagues that each experience has its own particular virtues that complement, rather than compete with each other. In an ideal world-and not one that we or our students are likely to inhabit in our lifetime-students would be introduced to various lawyering skills in the first year, would develop them in simulation courses as well as clinical courses in the second and third years (e.g. second semester second year, first semester third year), and then would have an externship in their final semester(s). This way, students could progressively develop their skill sets under laboratory conditions (simulations \& clinics), and then be plunged into the "real" world while they still had the opportunity to reflect on that world in seminar and through journals. But, as you have reminded me, we must deal with the world we have, and thus on to the next part of this conversation.

\section{Mary Jo:}

Understanding the interrelationship and potential symbiosis of in-house and externship clinics requires an examination of factors that go beyond pedagogy. There are political considerations, both within the individual law school and between the law school and the larger community, that have to be taken into account. The pedagogical validity of a clinical program may appear to be firmly grounded, and yet there may be resistance or criticism. Why? Among the reasons are political factors that relate to costs, perceptions about status and stability, and also relationships outside the law school with the legal and larger community.

There are some not well hidden secrets, seldom addressed directly, that concern the relationship between in-house and externship clinics and clinical teachers. These pertain to the politics, real and perceived, surrounding these programs and the law school community and administration. At least as far back as I can recall, there has been skepticism and at times hostility expressed by "traditional clinical" teachers toward externship clinics. ${ }^{28}$ The explicit criticisms pertain to the supposed lack of quality and legitimacy in externship course design and methodology - criticisms that are at times warranted. However, there are certainly strategic considerations that fuel some of the hostility, and these relate to the continued lack of parity between clinical and non-clinical faculty, and the failure of most law schools to provide full

\footnotetext{
28 I recall in my earliest days of attending clinical workshops and conferences in the mid -1980s, when I was teaching only in an in-house clinic, that many of the externship clinic teachers I met felt marginalized and disrespected by their in-house colleagues. Partly this was based on structural features of the workshops and conferences - very few if any of the topics and presentations were related to externship teaching and clinics. When I started teaching my first externship clinic in the early 1990s, I also became a co-chair of the AALS Clinical Section Externship Committee. We made it a practice simply to schedule Externship Committee meetings that were actually designed to present substantive material, including panels on goal setting, supervision and assessment.
} 
recognition and status protection to clinical teachers. In a nutshell, as long as clinical teachers continue to struggle for recognition, status and security within the academy, there is an incentive to marginalize their most immediate threat: the inexpensive externship clinic. ${ }^{29}$

The Report of the Association of American Law Schools - American Bar Association Committee on Guidelines for Clinical Legal Education [hereinafter " the Guidelines"], published in 1980, is explicit in addressing the immense cost differences between clinics and non-clinical courses, and between law school based (now known as in-house) clinics and field placement (now often called externship) clinics. ${ }^{30}$ According to the report, law school supervised clinics are among the most expensive courses in the law school curriculum ${ }^{31}$ while field-placement programs are among the least expensive - lower even than traditional, non-clinical courses ${ }^{32}$. In fact, the report at several points lists the direct cost per student of some field-placement courses as zero, when there is no classroom component. ${ }^{33}$

Clearly there is a strong financial incentive for a law school administration to move toward a zero cost, or relatively low cost clinical program, not only to supplement the overall curricular offerings, but also to supplant the very high cost in-house clinic. If there is little or no status protection for clinical teachers, as has historically been true, the zero cost externship model is a very serious threat to clinical education for a variety of reasons, some undeniably legitimately pedagogical. First, the zero cost or low cost clinic is based on either no faculty involvement, or a very high student faculty ratio. The calculations in the Guidelines go into a lot of detail to support the findings, ${ }^{34}$ but the concept is fairly easy. The fewer faculty resources devoted to a program, the lower its direct per student cost. This would be true whether the course is clinical or classroom, as the Guidelines explain. ${ }^{35}$ However, when the course is clinical, lower costs, and higher student teacher ratios, could result in a much poorer overall student learning experience, at least for in-house clinics. The same lowering of overall value to the student might not occur in a high enrollment externship, because the direct supervision is not impacted - only the classroom experience is affected. ${ }^{36}$ At least that is the premise of the Guidelines. I think we can

\footnotetext{
29 The struggle for parity has been ongoing, and well documented, most recently in the Report and Recommendations of the Status of Clinical Faculty in the Legal Academy. The Report traces the history of Standard 405, which is currently under consideration once again. Standard 405 (formerly c, now e) purports to provide some status protection to clinical teachers. Interestingly, the Report specifically eschews disparate treatment for various clinical faculty members within a law school, and appears to support the inclusion of field placement clinics (another name for Externship Clinics) within the definition of clinical course. Report at 42 and 9-10. See also Maher, supra note [15] for views on the forces behind the politics. Donald Schon's perspectives on this in Reflective Practitioner, relate this phenomenon to what he labels "a crisis of professional knowledge and a crisis of professional education," supra note [12, at 233.

${ }^{30}$ GUIDELINES, supra note [10].

${ }^{31} I d$. at 146.

${ }^{32} I d$. at 153 .

${ }^{33} I d$. at 143, 147 and 168. The Guidelines distinguish between direct costs, such as instructional, supervision and support, and indirect costs, such as contributing to the overall running of the school. It is primarily the direct costs that are considered in the report. Id. at 134 .

${ }^{34}$ Id. at $139-168$.

${ }^{35}$ Id. at $141-142$.

${ }^{36} I d$. at 142 .
} 
agree with the point that in-house clinics require student-teacher ratios that are lower than most other courses if they are to be quality learning experiences, and this tends to make them costly as compared with other law school courses.

\section{Marjorie:}

But in my case, since my seminar is half of my semester's teaching load, it's not as cost effective as assigning me to a traditional doctrinal class; it's as resource-heavy as any other clinic would be. Enrollment is limited to 15, and often, because of enrollees' last minute schedule changes, I have only 13 or 14.

\section{Mary Jo:}

Exactly! Many externship courses are not designed to be low or zero cost, and yet they seem to be included in the general criticism of externships. If you have even 15 students in your course, at this time (which is way different from 1984), that is a very good ratio.

\section{Part II}

\section{Designing, Teaching and Administering an Externship for Learning}

\section{Mary Jo:}

I have previously written about externship program design, focusing on the large externship clinic. I began teaching one such course in the early 1990s, and struggled to impose what I considered a legitimate set of goals and structure on a course that had evolved to some degree without a clear pedagogical plan. ${ }^{37}$ I will draw on my prior statements to some extent, but I also hope to pull in models that are quite different from the large externship courses that were the focus of that piece. When I was relatively new to clinical teaching I had the good fortune to be exposed to the teaching philosophy of a more experienced clinician. Professor Leah Wortham of Catholic University was the facilitator of my group at an AALS Clinical Conference sometime in the 1980s. Her mantra was "what are your goals?" After several days of hearing that question, in response to nearly every issue we discussed, I got it. ${ }^{38}$ Understanding goals is essential to the development of coherent program design. Without a solid grounding in pedagogical goals, any course can evolve to be an interesting and challenging experience, but, on the other hand, might simply become a hodge-podge of ideas and experiences, without any framework for assessment of success.

\footnotetext{
37 And I again note that, in my experience, this lack of program design - moving from the desired outcome to the structure and content of the course - can be a deficiency in in-house clinics, and indeed in non-clinical courses as well.

38 Leah Wortham is one of several co-authors and contributors to LEARNING FROM PRACTICE, originally published in 1998. See supra, note [].
} 
When I began to redesign Brooklyn Law School's large externship course in the early 1990s, there were few templates available to draw on for pedagogical inspiration. Clinical legal scholarship was developing, but scholarship about the design, content and pedagogy of externships was rare. There were a few articles on Judicial Externship Clinics. Learning from Practice, now in its second edition, was not published until 1998. ${ }^{39}$

My earlier article, Designing and Teaching the Large Externship Clinic, ${ }^{40}$ describes the path I took in my effort to identify the purpose (goals) and design (methodology) of the Civil Practice Internship Clinic. The path, much like any journey, began with an examination and selection of programmatic goals.

\section{Goals}

What are, or what should be, the goals of a clinical course? To answer this question we can take a few steps back, and look at the MacCrate Report, ${ }^{41}$ the Best Practices Report ${ }^{42}$ and the Carnegie Report. ${ }^{43}$ Although the MacCrate Report was not the first study to provide an overview of the skills and competencies required to enter the legal profession, it may be the first to give such a detailed analysis, listing 10 fundamental lawyering skills and 4 professional values, along with a full discussion of how these relate to both the practice of law and to the law school curriculum. $^{44}$ What the MacCrate Report provides is an outline of what the law school curriculum should be aiming to teach students, based on what the practicing lawyer should know and be able to do. Knowledge alone is not sufficient; lawyering skills must be developed as well. $^{45}$ The Carnegie Report more recently reviews law school curriculums to assess how well we are teaching the necessary skills and qualities of the legal professional. ${ }^{46}$ These two careful studies of the profession, and the education of the profession, should be the starting point of all curricular decisions. Unfortunately, except in those cases where a curriculum is being created from square one, most schools have achieved only limited success in realizing the promise of these works in guiding curricular design. Simply put, it is difficult to revamp hundreds of years

\footnotetext{
39 Id.

${ }^{40}$ Mary Jo Eyster, Designing and Teaching the Large Externship Clinic, 5 ClinICAL L. REV. 347 (1999).

${ }^{41}$ AMERICAN BAR AsSOCIATION TASK ForCE ON LAW SCHOOLS AND THE PROFESSION: NARROWING THE GAP, Legal EduCATion and Professional Development - An EduCATional ContinuUm (1992) [hereinafter “MACCRATE REPORT"].

${ }^{42}$ Roy Stuckey, et al, Best Practices for Legal EduCAtion, A Vision AND A RoAd Map (2007) [hereinafter "BEST PRACTICES"].

${ }^{43}$ William Sullivan, Anne Colby, Judith Welch Wegner, Lloyd Bond, LeE S. Shulman, EduCATing LAWYERS, PREPARATION FOR THE PROFESSION OF LAW (2007) [hereinafter “CARNEGIE REPORT”].

44 See MACCRATE REPORT, supra note (44). Following the publication of the MacCrate Report there were many articles written on its implications, and many schools took steps to examine their curriculums to evaluate how well each of the skills and values was being taught.

${ }^{45}$ See id. at $135-221$.

46 CARNEGIE REPORT, supra note () at [].
} 
of curricular design to respond to a more complete and complex understanding of what we must be teaching lawyers-to-be. ${ }^{47}$

Best Practices for Legal Education, drawing on both MacCrate and Carnegie, states that "[1] egal educators generally ignore long-recognized basic principles of curriculum development, which involves four stages . ..." 48 The stages are to identify educational objectives, to select learning experiences that are likely to lead to attainment of the objectives, to organize the learning experiences and to design methods of evaluating the effectiveness of the program. ${ }^{49}$ So, I think that in the development of any course, whether clinical or classroom, the educator should be considering what the goals are, what students will be expected to learn, and why this course is an important addition to the curricular choices already available to the student.

\section{Marjorie:}

I couldn't agree more that the departure point is Goals.

Because our program is much smaller than the one you administered, I only have students who are in their final year. So one of my goals is to help them navigate the transition from students to independent, autonomous lawyers. Clearly, that includes a basic understanding of at least some of the ways that law practices operate and an appreciation of the attributes of being a professional. It also includes teaching them the skills of how to work effectively with supervisors, both in terms of assignment clarification and effective feedback. And, most significantly, it includes figuring out what kind of practice will comport with their values, style and personality. ${ }^{50}$

As I mentioned, I was drawn to teaching the seminar because I want my students to be happy lawyers - and happy human beings. ${ }^{51}$ Students have remarked that when, during our

${ }^{47}$ The Carnegie Report makes the observation that most law schools address curricular change piecemeal, rather than from an overall and integrative perspective. Id. At [].

48 BEST PRACTICES, supra note () at 3.

${ }^{49} \mathrm{Id}$.

${ }^{50}$ See generally SusAn SWAIN DAICOFF, LAWYER, KNOW THYSELF (2003).

${ }^{51}$ As touchy-feely as that still sounds to many, happiness theory and psychology has clearly entered the mainstream's zeitgeist. See CAROL Graham, HapPiness Around the World (Oxford University Press 2009) (discussing the recent interest in studying happiness in the social sciences, the media, and countries around the world); Ed Diener \& Martin E.P. Seligman, Beyond Money: Toward an Economy of Well-Being, 5 PsYCHOL. SCI. PUB. INT. 1 (2004) (discussing the high development of happiness research and its future use for policy decisions by governments, organizations, and corporations); Carlin Flora, The Pursuit of Happiness, PsycholOGY TODAY, Jan. 1. 2009, http://www.psychologytoday.com/articles/200812/the-pursuit-happiness (describing the "Happiness Frenzy" evidenced by the increase in books published on happiness, the recent popularity of positive psychology classes at over a hundred universities, and the recently expanded body of research in both psychology and neuroscience on mental wellness and happiness). The country of Bhutan measures its national health based on a gross national happiness index, rather than on its gross domestic product (GDP). See Andrew C. Revkin, A New Measure of Well-being From a Happy Little Kingdom, N.Y. TiMES, Oct. 4, 2005, at F1. An organization in the state of Vermont has a project aimed at persuading the United States to follow Bhutan's example. See Andy Bromage, 
first class, I ask them to complete Susan Daicoff's "Values Inventory," ${ }^{52}$ or we do the Eulogy exercise, ${ }^{53}$ it is the first time that anyone in law school has asked them about what matters to them.

In his wonderful book, The Courage to Teach, Parker Palmer writes that "we teach who we are. ${ }^{54}$ In order to be effective teachers, we need to know ourselves.

Teaching, like any truly human activity, emerges from one's inwardness, for better or worse. As I teach, I project the condition of my soul onto my students, my subject, and our way of being together. The entanglements I experience in the classroom are often no more or less than the convolutions of my inner life. Viewed from this angle, teaching holds a mirror to the soul. If I am willing to look in that mirror and not run from what I see, I have a chance to gain self-knowledge - and knowing myself is as crucial to good teaching as knowing my students and my subject.

The work required to "know thyself" is neither selfish nor narcissistic. Whatever self-knowledge we attain as teachers will serve our students and our scholarship well. Good teaching requires self-knowledge; it is a secret hidden in plain sight.

Who am I? I am introspective. When I began to write about emotional competence, a concept encompassing both self-knowledge and interpersonal skills, I felt I had found my calling, at least with respect to my writing agenda, for the foreseeable future. In teaching my externship seminar, I am not only teaching my students how important such competence is to good lawyering, the subject of much of my writing. ${ }^{55} \mathrm{I}$ am also teaching them how important self-knowledge is to knowing who they want to be as lawyers.

Happiness Is... A new Vermont non-profit wants to replace GDP with GNH, SEVEN DAYS NEWSPAPER, Apr. 28, 2010, http://7dvt.com/2010gross-national-happiness . The proceedings of a 2007 University of Chicago Law and Economics conference symposium on Law and Happiness were published by both the Journal of Legal Studies and in book form by the University of Chicago Press. LAW AND HAPPINESS 1 (Eric A. Posner \& Cass R. Sunstein, eds. 2010). Also, a plethora of law review articles with 'Happiness' in the title have erupted over the last few years. See, e.g., Peter H. Huang, Happiness Studies \& Legal Policy (forthcoming 6 ANN. REV. OF LAW \& Social ScIENCE (December 2010); Betsey Stevenson \& Justin Wolfers, Happiness Inequality in the United States: Legal implications of the new research on happiness, 37 J. LEgAL STUD. S33 (2008); Rick Swedloff \& Peter H. Huang, Tort Damages and the New Science of Happiness, 85 IND. L. J. 553 (2010).

${ }^{52}$ Susan Daicoff, Lawyer Personality Traits and their Relationship to Various Approaches to Lawyering, ch. 3, AfFeCtive Assistance OF Counsel, supra note [] at pp. 101-07. See infra, text at note [journal questions].

${ }^{53}$ Lawrence Krieger, Professional Identity, Core Values, and Stress Relief for Law Students (and Lawyers), http://humanizingideas.law.fsu.edu/forum_posts.asp?TID=16\&PID=122\#122 (last visited 8/1/10). See infra, text at note [journal questions].

${ }^{54}$ Parker J. Palmer, The Courage to Teach 1 (1998).

${ }^{55}$ Marjorie A. Silver, Emotional Competence and the Lawyer's Journey, in AFFECTIVE AsSIST ANCE OF COUNSEL, supra note [], ch. 1 at 5; Marjorie A. Silver, Supporting Attorneys' Personal Skills, 78 REVISTA JURIDICA EsCUELA DE DERECHO U. PUERTo RICO 147 (2009). Marjorie A. Silver, The Professional Responsibility of Clinics: Emotional Competence, Multiculturalism \& Ethics, 13 JouRnAL OF LAW AND MEDICINE 431 (2006); Marjorie A. 
I am a problem-solver; I don't give-up in the face of adversity until I have exhausted all possible strategies for resolving a given problem. When we spend class time brainstorming solutions to problems that arise in one or another of their placements, I am teaching my students problem-solving skills. I am a collaborator. I often ask the students to get together into groups of two or three to think up solutions to their classmate's problem. In part, I do this to get everyone actively participating, but I am also teaching them collaboration skills. When we discuss the best ways to address a concern with their supervisor, I am teaching them how to be effective communicators. When disappointments arise in their placements - a case they have been working on settles, or anticipated opportunities fail to materialize-we brainstorm how to create alternative opportunities. Thus I endeavor to teach them resilience.

Above all, I am a happy person who loves my work and my life. So many of my students fear that being a lawyer means losing balance, ${ }^{56}$ that in order to be "successful" they will have little time for family and friends. Many describe how the lawyers that they know are unhappy, how others have attempted to discourage them from a legal career.

Although I present a counter-example, as you have pointed out, most of our students will not become law professors. ${ }^{57}$ [I truly believe this is the best job in the world.] By bringing to class a variety of lawyers who have achieved balance and wellbeing in their lives, my students get to see other, far more positive and optimistic aspects of law practice. ${ }^{58}$

\section{Mary Jo:}

It would be wonderful if your students could absorb even a bit of this positive energy. Your statement about helping your students navigate the transition from students to independent, autonomous lawyers resonates with me. I think in a sense it captures the essence of what we are doing by giving students the opportunity to practice as lawyers, whether in-house or in outside placements.

I am going to make a statement which some might find bold, and maybe provocative. Externship clinical courses are able to offer learning opportunities that will better achieve some legitimate educational goals. The inquiry about value and legitimacy should be centered on the integrity of the course design, and its adherence to stated goals, rather than about how closely the

Silver, Emotional Competence, Multicultural Lawyering and Race, 3 Fla. COASTAL L. REV. 219 (2002); Marjorie A. Silver, Emotional Intelligence and Legal Education, 5 J. PsychOL. Pub. POL'Y \& L. 1173 ( 1999); Love \& Hate, supra note [2].

${ }^{56}$ These fears arise not only in the exercises and discussions we have in seminar, but in anonymous surveys I do each time I teach Professional Responsibility of what concerns my students most.

${ }^{57}$ See supra text at note [13].

${ }^{58}$ See Maranville, supra, note [] at 136 ("In the best of circumstances the supervisor functions as a role model for one way of finding a satisfying - passionate-life in the law...."). To be sure, in this economy, many of my students will be thrilled to find any job, let alone one that excites their passions. But the current economic climate will change, and it is essential that they not lose sight of what matters to them as they make choices on how to spend their lives in the law. 
externship tracks and resembles an in-house clinic. Put another way, there are many courses, both clinical and traditional, that lack pedagogical value, either because there are no clear and legitimate learning goals, or because the program is not carefully designed to achieve those goals. The carefully designed externship clinic enhances the overall curriculum, and should be welcomed as an essential part of the pedagogical experience.

Here are some of the ways in which I believe an externship clinic can add value to the law school curriculum.

1. Critical examination of the ethics and practice of lawyering

2. Examination and assessment of models of client service and advocacy

3. Introduction to the skills necessary to develop and excel as a professional

4. Opportunity to test skills and knowledge as applied, to gain a fuller appreciation of the nuances of substantive and procedural law

5. Insight into the tensions of practice, including conflicts between professional obligations and personal values and moral beliefs.

Within an individual program there can be more specific goals, and indeed individual students are encouraged to set their own goals within the broad framework. My own programmatic goals are, I think, encompassed in this list.

\section{The Realities of Law Practice}

\section{Marjorie:}

As you know, the reason I wanted to write this article with you in the first place was my belief that externships add value to the students' legal education in ways that in-house clinics cannot, or at least not as well. So let's get specific. I mentioned that each week I have a guest lawyer come speak to the class. Through their stories, students experience a wide variety of important lessons about a life in the law. Their learning is reflected in both class discussions and their journals. One important lesson is about resilience. Here are some examples:

\section{MP:}

One of our guests, MP, is an in-house lawyer with National Grid, a British company. National Grid took over the Long Island utility company, Keyspan, a few years ago. Prior to the takeover, MP was a full time litigator for Keyspan, and she absolutely loved her work. One of those people with seemingly boundless energy and enthusiasm, MP had managed to successfully juggle motherhood, marriage and career. ${ }^{59}$ Following a less than happy stint

\footnotetext{
59 MP's husband is an attorney as well. When the students in the fall of 2009 learned that he worked for the U.S. Dept. of Homeland Security, one student interested in immigration law opportunities and another interested in
} 
working for a private practitioner after law school, she had fallen into the position with Keyspan. She would have been perfectly happy to keep litigating for Keyspan for the indefinite future. Then the take-over happened and what had seemed like a stable, ideal situation was now a big question mark. National Grid, whose U.S. headquarters are in Boston, had decided to consolidate their in-house litigation department in the Boston office. They offered MP an opportunity to stay on in the Long Island office in a completely different capacity, as the equal employment compliance officer. It meant giving up litigation. It meant learning a whole new area of the law. It was a total change.

But, as she told the students, the saying that one door closes and another opens is absolutely true. MP discovered that she loved this work even more than she had loved litigation. She enjoyed the amount of people contact that it entailed. She welcomed the challenge of learning a whole new area. And she certainly didn't mind the opportunities for travel to both Boston and London.

The take-away? That you just never know. Adversity often does metamorphose into exciting opportunity.

\section{SS \& RB:}

SS \& RB were already a couple when they joined my seminar in the fall of 2007 . Despite being highly qualified, neither had a job by the time they graduated. SS had, in fact, received an offer from the firm at which she externed. However, while it was a very valuable experience from which she learned a lot - she even got to author a brief for the Second Circuit - the most important lesson she learned was what she didn't want. She reported that there was no work/life balance in the firm, and many of the lawyers interacted like a dysfunctional family. Stress was the primary emotion permeating the office.

When I saw SS \& RB several months later, however, they had each secured positions in local government-and were enjoying their work, and lives, enormously. Their work afforded them regular hours and plenty of time for R\&R. They both came as guests to the seminar for one class last fall, and they, truly, could put themselves in the current students' shoes-and vice versa. Journals written after their visit reflected how reassuring it was that these two recent Touro alumni not only landed jobs within a relatively short period of time, but were extremely happy with their new positions. ${ }^{60}$

\footnotetext{
learning more about employment with the federal government, encouraged me to ask him to come as our guest, a request to which he readily agreed. Thus one guest's "contacts" led to an invitation to another guest who specifically responded to student interests.

${ }^{60}$ [Insert journal excerpts]
} 
MM:

MM, a 2006 alumna, had been both my teaching assistant and my research assistant, at different points. Although she took the other courses I taught, MM had never taken the externship seminar. She loved law school, excelled at it, but she had engaged in a fair amount of denial about the need to consider her future employment, something she readily shared with the class when I alluded to it. In her last semester, however, MM took a seminar with adjunct professor FB, perhaps Long Island's most renowned plaintiffs' civil rights attorney. Then and there she decided that she wanted to practice civil rights law, and she wanted to work in FB's office. His policy, however, was not to hire lawyers who hadn't had at least two years experience. Furthermore, as his office was quite small, FB didn't do much hiring at all. Not easily dissuaded, MM volunteered to work for FB for free, even while she was studying for the bar exam, as well as for a few months thereafter, to prove that she would bring value to his office. And she did. And he hired her that fall.

This was the story she told the first year she visited my seminar, in the fall of 2007. It was a story of the benefit of tenacity, of not giving up on a goal until you had given it your everything. It was incredibly inspiring. ${ }^{61}$

MM visited again in 2008 and 2009, and I delighted in watching her maturation into a selfassured practitioner. At her last visit, she told stories of what she had discovered about herself, about her ability to sell clients on good deals. ${ }^{62}$ This was a story about self-discovery, about

\footnotetext{
${ }^{61}$ [Plug in quotes from journals.]

${ }^{62}$ I thought these stories were such excellent examples of emotional competence and creative problem-solving that I shared them at a workshop I gave on Emotional Intelligence and the Lawyer's Journey for clinical students and faculty at Albany law school in October 2009:
}

\section{The Discrimination Case}

After 9/11, the client, a Muslim Indian-American female physician was subjected to a hostile work environment (discriminatory comments, etc.) and subsequently fired from the hospital in which she held an important position. On the facts, it was a really strong case. However, the client didn't come see a lawyer until after the statute of limitations had run on most of her claims that required the complaint first be filed with the state human rights agency or EEOC. To avoid the headache of litigating the case, however, the hospital offered her a $\$ 25,000$ settlement. The client refused to take it. No one in $\mathrm{MM}^{\prime}$ ' firm was able to persuade her that it was a really good settlement, given the circumstances. The client didn't want the defendants to buy her off for so little, to get away with what they had done to her.

MM spoke with the client, acknowledged that she was understandably and appropriately furious, but that the law would likely preclude her from recovering anything. Furthermore, the people at fault would not be punished, would not lose their jobs. An insurance company would pay, not the hospital or the administrators. In addition, MM knew that the client's need for vindication would not be achieved by any sum of money. 
evolving into someone you hadn't imagined you could be. How exciting to learn new talents you possessed as your career developed! And the students' subsequent journals reflected that excitement. $^{63}$

Mary Jo:

There are really so many examples of this type of resilience. Often students are expecting a particular type of case work, or even a specific case. The work shifts, the case settles, the office moves in a different direction. I guess one could argue that this is one of the down-sides to the externship, and a value of the in-house setting, where case loads can be more carefully controlled. However, in my own experience, these same disappointments can occur in the inhouse setting.

\section{Marjorie:}

Not only that, but this is life. This is law practice. I aspire to bring lessons about the importance of developing resilience through hearing from practitioners who have had to do so, and through grappling with problems and disappointments that arise in their placements.

MM acknowledged the injustice and the client's desire for retribution, but kept coming back to the fact that she wouldn't be able to get that through legal processes. MM also said the client could go through life with this anger, but the only one it would hurt would be herself. She suggested the client turn to her religion to make peace with this. The client finally agreed to accept the settlement.

\section{The Malpractice Case}

This client's son had a serious medical problem requiring surgery. After surgery, he developed serious complications. MM's firm consulted top notch medical experts to establish medical malpractice on the part of the surgical doctor. None of these experts could confirm that malpractice caused the boy's complications.

Upon hearing this, the client requested that the firm attempt to get "some" money from the defendants. The hospital offered $\$ 20,000$; nonetheless the client rejected the offer. The client was furious at everyone, including MM's firm. She threatened to file a malpractice action, a grievance, etc . The firm was ready to file a motion to be dismissed from the case for "irreconcilable differences" with the client. MM asked to give it a try.

Once again, MM tried to explain to the client (who continually cursed at MM) that they would be unable to prove a link between what the surgeon did and her son's injury. The client wanted the doctor to be held accountable. MM again explained that it would be the insurance company, not the doctor, who would pay any damages. MM suggested that the client could take the settlement, and still vent her fury at the doctor by writing an article about him, and MM would even try to help her get it published. The client finally relented.

${ }^{63}$ [Ditto re: journal excerpts]. 
Preparing students to expect the unexpected and respond creatively and proactively is critically important to readying them for the world of indeterminacy ${ }^{64}$ they are about to enter.

\section{Mary Jo:}

I like the way that you express that. It's really an important perspective - similar to, but also different than, the idea of real world practice. Both the clients and the lawyers have to deal with disappointments, changes in their expectations, facts, law and circumstances that don't lead where they want to go. I think these observations relate to the first goal that I indentified - the critical examination of the ethics and practice of lawyering. The pressures and demands of an operating law office, with heavy caseloads or pressing regulatory mandates, provide a context for critical examination of the practice of law that is unlikely to be replicated in an in-house clinic. Students will benefit enormously from the opportunity to process these experiences, observations and questions under the guided classroom discussion of a member of the law school faculty who has the distance to provide objective views, and the experience to understand the practical realities.

Both the in-house and externship clinic can provide opportunities to examine the ethics and practice of law. Indeed, critical examination of lawyering should be inherent to some extent in any law course, whether clinical or classroom. In the externship clinic, the experience that will provide the fodder for discussion and review is likely to have an authenticity that does not occur in most in-house clinics. Students who are interns in real operating law offices and agencies will be able to observe and take part in law practice in the faster paced, less structured and potentially chaotic world in which many lawyers, especially lawyers in legal services and government offices, must operate. The demands of clients, even in the not-for-profit setting, may exert much more pressure than in the in-house clinic setting. Ideally there will be a balance between providing adequate guidance and review, and also a candid view of the practice of law. However, as a participant and observer, the student in the externship clinic will have an opportunity to witness firsthand how the pace and demands of actual legal practice are met by the lawyers in that office. S/he will have a vantage point from which to assess the success and failure of various lawyering practices. S/he may observe decision making or practices that raise ethical issues that are less clear in practice than in classroom discussions. In a practice setting the pressure to win a case may at times push the supervising attorney into more dubious ethical choices.

Presumably faculty members directing an in-house clinic will be attentive to honoring both the letter and spirit of ethical norms in their supervision and direction of the clinic's cases. This is, in fact, one of the great values of the in-house clinic learning experience. The students are given ample time and support to reflect consciously and with care before making decisions, both about legal strategy and about ethics. In most in-house clinics, case loads are limited and cases

\footnotetext{
${ }^{64}$ Robert Dinerstein \& Elliott S. Milstein, Uncertainty and Indeterminacy as Over-arching Themes in Clinical Pedagogy (work-in-progress).
} 
selected with the goal of providing a well-structured and manageable work flow to the students in the program. However, in some ways, this careful structure is also a disadvantage, as the coarse reality of practice is missing. ${ }^{65}$ And, as has been argued in a criticism of in-house clinics, it may be difficult for both faculty and students in the in-house setting to be objective in critiquing their own practices. No matter how open and introspective we strive to be in teaching our students, we must on some level believe in the merits of our own lawyering. ${ }^{66}$ We may not be as open to alternative viewpoints as we imagine.

In the externship clinic there can be some distance between what is happening in the field and the discussion and lessons to be derived from the experience. The faculty seminar teacher is not directly involved in the decisions taking place in the field, and may offer perspectives that differ from the views of the field supervisor. This does not mean that the faculty will normally question or dispute the decisions, but merely that there can be a more candid, objective discussion when one's own performance is not the topic under review.

My students often comment on their discoveries about the ethics and practice of lawyering. I asked some of my students for permission to borrow from their final essays from this past semester. I told them it would be anonymous, and so I will be leaving out any identifying information. Here are some of the students' comments about this goal.

GB: My task was to document the health studies used to substantiate their claims and determine whether they met the applicable standards .... At first, I felt that the work was not going to help achieve my primary goals of litigation experience. However, shortly after beginning work, I realized how significant the assignment was to the process of litigating a case on behalf of the ... office and I realized that I was learning a lot more than I had originally believed. I realized that all cases require substantial preliminary investigation and attorneys must do significant legal research and analysis before ever commencing a suit.... I felt this experience, observing the attorneys think about a case, identify the relevant issues and identify legal questions that can solve the problem, was a very valuable learning experience that directly contributed to helping me achieve my goals.

HM: This experience gave me a first-hand glimpse into all phases of the trial process. It was also interesting to observe the litigation process during the same semester that I was competing with the Trial Advocacy [team]. I saw attorneys do many things that we are taught to never do .... I think the entirety of chambers' interrelated work was the most important part of the externship because it gave me a glimpse into how I will work in the future as a trial attorney before a judge. I now know what type of research and writing is acceptable for an attorney to submit to a judge, how a judge and his/her clerks consider, research, and respond to parties'

\footnotetext{
${ }^{65}$ There are some students who seem to respond better to the outside placement, where they know they are working at the same pace, with the same pressures, as practicing lawyers. For some students, the work in the in-house clinic may be treated like other course work - some will let things slide because they perceive that either the work will wait or the supervisor will step in. But, for whatever assorted reasons, there are some students who gravitate to the externship setting where they feel they are challenged, and must prove their ability to rise to the challenge.

${ }^{66}$ See infra notes [84-85] and text accompanying.
} 
submissions, and how hearings and trials are conducted before a judge. My externship was a type of inside on the job training for my future.

What I think these types of comments reflect is the tremendous value students derive from being immersed in the ways that practicing law may be different, more nuanced possibly, more multi-faceted, than their conception of law practice. It is satisfying for me to read these types of "epiphanies" about the practice of law, and to see how students process their discoveries.

\section{Negotiating Work and Life}

\section{Marjorie:}

As you know, I was drawn to this work out of concern that there are just too many unhappy lawyers out there in practice. ${ }^{67}$ One reason this is so is because their lives are so out of balance. More than ever, I find that students today are concerned -and appropriately so-with how they will balance work with the rest of their lives, especially time with family and friends. One of my students confessed that she thought it was unprofessional to even acknowledge such concerns! $^{68}$ An important goal for me, therefore, is to explore in seminar how not only this is possible, but that it is essential. Unless the caregiver takes care of herself, she is in no position to care for others, and this is as true for lawyers as for doctors, social workers - and parents. ${ }^{69}$ They need to figure out how they will be able to achieve this in the long run, so that they don't end up as unhappy lawyers and unhappy people.

The guests I bring to class provide numerous and varied alternatives for achieving this balance. RK shares how he hated, as an associate in a medium-sized Long Island firm, being a slave to the billable hour. He says now, as a solo practitioner, he works just as hard, but he has the autonomy to decide when and where that work occurs. He can leave the office at 3 o'clock in the afternoon to go watch his son's soccer game, and return to the office, if necessary, after dinner.

LEH practiced matrimonial law the traditional way, as a litigator, before she discovered mediation and collaborative law. ${ }^{70}$ The students were impressed with how she was able to control her schedule with this shift and thus be more available to her children.

FKB, the civil rights attorney for whom MM worked, ${ }^{71}$ finds time to sing in his church choir and regularly coaches the local high school football team. ${ }^{72}$

\footnotetext{
${ }^{67}$ [cite]

${ }^{68}$ [Cite AB.]

${ }^{69}$ [Cite]

${ }^{70}$ [cite].
} 
I share with my students my own career path, which enabled me to spend 32 years parenting two "only" children, ${ }^{73}$ by working first for the federal government and later as a law professor. And now, as an empty nester, I maintain that balance through, among other things, meditation, yoga, harvesting at my community farm on the East End of Long Island, and doting on my grandson. ${ }^{74}$

Now, Mary Jo, I anticipate that you will suggest that I have oversimplified the quest to find work/life balance, and you would be absolutely correct. I have painted with a broad brush, and I know that finding balance is never so easy. The day-to-day pressures of practice that our students will experience in their placements will bring home, far better than the seminar is able, the challenges of achieving balance-however they define it-in their work and in their lives.

\section{Mary Jo:}

Oversimplified? No, not at all. It's not that it is hard, or simple, but that it is an articulated and achievable goal. It's interesting that your student thought it would be unprofessional to even raise those concerns. However, thinking back to my days as an associate in a big firm, I think most of the women (and probably many of the men) would have considered their concerns about their personal/professional life balance to be signs that they were not really cut out for this type of career. This is part of the focus I think about when I refer to my goal of giving students insight into the tensions of practice, including conflicts between professional obligations and personal values and moral beliefs. Certainly the value of time, family, community and health are among those that should be weighed. My concept may be broader than yours because I'm also thinking about the fit between the student, as a person, and the demands of practice in general, as well as the particular setting.

The externship experience will expose students to many practice settings with many different supervisors; in some offices-multiple supervisors. Unlike the in-house clinic, there will not always be a thoughtful design that considers case selection and workloads based on a realistic assessment of students' other course and life demands. In-house clinics can be demanding, and the case requirements can be unpredictable. Nonetheless, the faculty supervisor is fully aware of the patterns of the cases, and synchronization with the law school calendar. Typically we are able to alert students to likely upcoming demands and possible conflicts, and to plan to address them before they overwhelm the student. In practice, and in the externship setting, these

\footnotetext{
${ }^{71}$ See supra, text at notes []. MM, having found a lack of work/life balance in what was otherwise three glorious years in his office, recently accepted a position as law secretary to a New York Supreme Court justice. She reports missing the excitement of private practice, but loving the time she gets to spend with family and friends.

${ }^{72}$ FKB and his wife have no children of their own; I have never asked, but often wondered, whether this was a decision related to his career choices.

${ }^{73}$ My daughter, Lucy, was born when my son, Josh, was fourteen. I had children at home until Lucy left for college at age 18 .

${ }^{74}$ Granddaughter to be added in October!
} 
scheduling demands and conflicts may not always be anticipated, creating more stress. Students are then required to figure out how to respond in a manner that is both professionally and personally acceptable.

Beyond the stresses of scheduling, there often are other types of stressors in the externship setting that may not occur in the in-house clinic. Students are unlikely to enroll in an in-house clinic if they feel no affinity for the type of practice or the client base the clinic is designed for. In practice, however, students will often find themselves assigned to work on a case, or with a client, that is a challenge to the student's political, moral or other personal beliefs. Obviously students choose the settings in which they work, but they are rarely fully informed of all of the types of cases and clients that they might encounter.

Similarly, their own supervisors may have attitudes about some of the work or some of the clients that introduce tensions between professional obligation and personal preference. Learning how to navigate the terrain of professionalism in a manner that does not disrupt one's ethical standards is an invaluable lesson for the law student, and for the young (or even not-soyoung) lawyer. In the classroom it is easy to fall into the rote lessons about the lawyer's duty to represent the client zealously, within the bounds of the law. In practice, choices about what actions to take, and to avoid, are not so simple. And respectable honest practitioners may not always reach the same answer to these questions. ${ }^{75}$

\section{Marjorie:}

Yes, and another advantage is that my students learn from counter-examples of lawyers with whom they work who lack work/life balance. As with SS, ${ }^{76}$ who learned she did not want to work in a firm where the lawyers didn't even have photos of their family on their desks (and perhaps didn't have families!), my students continue to use externships to rule out future employment possibilities. Some journal examples follow:

PW: I never really thought about it but after class I realized that it is important to consider two main factors when choosing a field of law. First, my intellectual capacity to understand the work that I would be doing. Secondly, my emotional capacity. Would I be able to leave my job at my office? Would I have a constant struggle between what I feel is right versus what my clients believe in?

SR: Through both the actual placement and the seminar, I found that I learned a lot about myself as well as my goals for the future. I had never really taken the time to consider what type of attorney I wanted to be or the possible alternatives to litigating. This experience has provided me the foundation I need to continue reflecting on my work and personal goals and the necessary steps to achieve them.

\footnotetext{
${ }^{75}$ Marjorie: This is not to suggest, of course, that students might not be exposed to poor practices in their placements, as much as we might endeavor to avoid having that occur. See Eyster, supra note [] at 393 (discussing how to handle student reports of incompetent or less than diligent practices in placements).

${ }^{76}$ See supra, text at note [].
} 
Additionally, I learned that I have a tendency to become so absorbed by work and what needs to be completed that I forget to consider work/life balance and lose the balance totally. I am now cognizant of this tendency and can work to strike more of a work/life balance. If not, I have learned that the future does not look so bright and there is a possibility of burning out.

Overall, my ultimate goal is to be a successful, happy attorney that feels both satisfied with my work as an attorney and fulfilled in my personal life. I learned through this experience that work/life balance is absolutely possible, but will take work and conscious effort. In order for this goal to be fulfilled, I must be conscious of my time-spent working and recognize when it is time for my family and friends.

\section{Mary Jo:}

Yes, I, too, have read many student essays where they express great appreciation for having had the opportunity to learn, not only what they do like in practice, but what does not inspire them or meet their work style needs. While this type of realization could occur in the in-house setting, the real world context of a field placement makes it much more likely that the student will discover what "clicks" or what does not. Here are some observations about their discoveries:

LG: I've learned that while I like working for the [office] and I might like to have a position in this office or a similar office someday, I would like to experience work in a more fast-paced environment. ... This is not really a criticism of the office. It's more of something I've learned about myself - I like to be pushed and challenged and I like to always be busy at work. For next year, I am going to try to find an internship where I can work on similar issues, but in a different environment. ... Without my experience at [this office] I would not know this about myself.

AS: After this internship, my love and excitement of the courtroom has worn off a little bit and I think I may not be as interested in it. This makes me value my time as [an] intern even more, however. I think it is as important to learn what one is not interested in as it is to learn what one is interested in. Classroom education is not capable of helping with this, nor is it designed to. This practical experience, seeing how [the process] works . . . is invaluable for understanding personal interests.

\section{Exposure to Alternative Careers}

\section{Marjorie:}

Of course, it is equally important that students have an opportunity, before they graduate, to discover alternative career choices that are compatible with their values and life goals. An additional virtue of a general externship program like mine is the opportunities for students to gain exposure to a wide range of possible career choices. This happens through sharing in seminar the experiences they have in the variety of their placements - we do "rounds" virtually 
every week - and in hearing about the career paths of our guests ${ }^{77}$ An in-house clinic cannot afford these opportunities.

\section{Mary Jo:}

Marjorie, I'm going to relate these comments to one of the goals that I identified above, because I think they are fairly closely tied. That is, the examination and assessment of models of client service and advocacy. There are many approaches to client representation, including direct service, law reform, a variety of dispute resolution methods, transactional work, individual and group client advocacy, all offered in government, private law offices and not for profit settings. Seasoned practitioners may have experience in more than one of these possible environments, and have probably at least examined some of the alternates from close contact in their client work. For the law student, the opportunity to examine and evaluate the myriad approaches to client representation is instructive and invaluable. Diverse placement opportunities give individual students options about the type of practice they want to experience, and the classroom experience will often draw a range of these placements into the same discussion. This combination of field placement opportunities and classroom integration of experiences helps students to understand and evaluate the effectiveness, and the limitations, of various lawyering models.

For example, when I was teaching the seminar for students in the Individual Rights Seminar, I had some students in law reform offices, some in direct service offices, some in NGOs and others in government regulatory/enforcement offices. All of these students and offices were loosely engaged in the same endeavor - the enhancement and protection of individual civil and human rights. The diversity in their offices' work, and their differing appraisals of both the strengths and weaknesses of these approaches, provided for a rich exchange of perspectives in the classroom. We often analyzed their individual casework from these varying perspectives an exercise that sparked much greater insight than they could have achieved if they considered solely the model of representation that they were directly involved in. I think this opportunity is incredibly valuable for law students, as it allows them to take their interest or passion for a particular type of legal work, and to consider how they might feel most effective in pursuing that interest. The diversity of practice settings that is possible in an externship clinic can hardly be replicated within one law school's in-house clinics. And, while the theoretical discussion of models of service can certainly be pursued by a combination of readings and guest lecturers, the

\footnotetext{
${ }^{77}$ See this excerpt from SR's final journal:
}

A common theme of my journals was overall enthusiasm for our guest speakers. I found much of what each of our guests had to say extremely helpful in planning for the future and informative about areas of the law that I was relatively unfamiliar. Each of the speakers provided great insight and was extremely informative about the area of law they each practice. I really feel as though I learned so much about different aspects of law and the possible alternatives to the "big firm." I also found each guest speaker to be candid about the process of finding jobs and the paths taken to find the right legal job. 
immediacy of actual practice experiences, shared through student discussions, brings the reality that is generally connected with clinical education into the discussion. One of the students makes this observation:

GB: This experience also taught me something about government litigation: that multi-agency enforcement can often lead to inefficient allocation of resources and can often lead to wasted efforts and frustration.

And another observed:

LG: I would like to work for [a similar office] someday, but I think I would prefer it be later in my life, when I could get a more advanced position so that I could improve the efficiency of the office.

\section{Marjorie}

This is terrific, Mary Jo. Really inspiring. You've demonstrated that the value I ascribe to a "general" civil externship clinic with diverse placements, can exist as well in this kind of "subject-matter specific," program, when there are a variety of placement settings. So let's discuss the topic directly: how do we choose placement settings to meet the goals we have set?

\section{Placement Selection}

\section{Marjorie:}

There is a good amount of controversy over whether it is appropriate to place students in private firms and corporations. ${ }^{78}$ Touro made the decision to do so a few years before I began

\footnotetext{
${ }^{78}$ See James H. Backman, Where do externships fit? A New Paradigm is Needed: Marshaling law school resources to provide an externship for every student, 56 J. LEGAL. EDUC. 615, 630 (2006) (stating that private sector placement will increase the variety of placement sites and lead to more students becoming involved in the program); Bernadette T. Feely, Examining the Use of For-Profit Placements in Law School Programs, 14 CLINICAL L. REv. 37, 47-49 (2007) (discussing the benefits of private placements: that it will increase both the amount and subject matter of the externships, provide more opportunities for students to explore different careers, demonstrate pro-bono modeling in the private sector, and provide opportunities for alumni in the private bar to become involved; while also acknowledging that allowing for private placements would move students away from the primary goal of externships which is to promote public interest work, raise concerns that private sector attorneys would provide less supervision and less important work to the students, and would strongly strain the amount of resources available for the programs); David L. Gregory, The Problematic Employment Dynamics of Student Internships, 12 NOTRE DAME J.L. ETHICS \& PUB. POL'Y 227, 261 (1998) (noting that many private firms keep unpaid interns instead of hiring paid workers, because they can use the interns to do the "work that another full time, permanent (and paid!) employee would normally do."); Peter Jaszi et al., Experience as Text: The History of Externship Pedagogy at the Washington College of Law, American University, 5 CLINICAL L. REv. 403, 429 (1999) (arguing that students should be placed in the private sector, because the "same kinds of learning" found in the public sector are available in the private sector, it would broaden the placement options available by allowing students to work in both public and private sectors, and it would create the opportunity for students to compare and contrast the experience of externing at private vs. public placement sites); Steven Greenhouse, The Unpaid Intern, Legal or Not, N.Y. TIMES, Apr. 3, 2010, at B1 (recognizing the issue of interns being used to displace workers and the lack of educational supervision). Relatively recent concerns involve legal issues of the compatibility of unpaid externships with the Fair Labor Standards Act. See Hilary Stout, Students Chafe Under Internship Guidelines, N.Y. TIMES, July 4, 2010, at ST1 (discussing the challenge presently facing employers to design their internship programs to be consistent with the Fair Labor Standards Act, leading many employers to cut back on unpaid internships or stop them completely).
} 
teaching the seminar. Although initially skeptical, and still mindful of many of the potential pitfalls it creates, ${ }^{79}$ I believe it has served several important purposes, not the least of which is giving students the opportunity to extern in settings in which they ultimately may want to practice. $^{80}$

\section{Mary Jo:}

I think this is an example of where goals have to drive process. When I began teaching our largest externship clinic, the Civil Practice Externship, we had a general rule that only government and not-for-profit placements would be approved for credit. That is still the "rule" but there are some exceptions. On the other hand, there are some very high quality programs that I know of where students have routinely been permitted to intern in law firms or in for-profit settings. You are right about the concerns about billing clients, but I'm not really sure the profit rather than pedagogy point is so compelling. Pedagogy is, quite honestly, not the primary objective of any of the field placements. By that I mean that the field supervisor's primary focus has to be on serving the client and performing his or her role as a lawyer. But as I've said, I don't think this is a fatal shortcoming.

As I discussed earlier, ${ }^{81}$ without first establishing clear goals it does not make sense to make any decisions about appropriate placements. The decision about virtually every aspect of clinic design should flow from understanding goals. I think this type of premature planning affects inhouse clinics and externships alike. What I mean by this is, many of us have a tendency to select a genre of cases, or focus areas, or to select field placement offices, without fully exploring the purposes of our choices. How can we determine whether a specific case, or type of case, or law

\footnotetext{
${ }^{79}$ My concerns are largely focused on the profit motive of firms and the risk of their viewing students as unpaid laborers. See Greenhouse, supra note [].

${ }^{80}$ For example, in the fall of 2009 my students were placed as follows:
}

- New Jersey Attorney General's Office

- New York Attorney General (Long Island branch office)

- Nassau County Attorney's Office

- A large Long Island firm

- A medium-sized Long Island general civil practice firm

- A medium-sized Long Island personal injury defense firm

- A medium-sized New York City general civil practice firm

- A boutique Long Island IP firm

- A small general practice New York City firm

- A family-owned personal injury firm

- A solo practitioner of immigration law

- A solo practitioner of entertainment $\&$ sports law

- Corporate counsel at a large retail chain

81 See discussion infra, notes [34 to 37] and accompanying text. 
office setting, will be a good choice if we do not have a solid grasp of our pedagogical goals and our proposed path to reaching those goals?

\section{Marjorie:}

Confession: I didn't think about overall curricula goals in designing my seminar, but rather the underserved goals that I wished to champion.

\section{Mary Jo:}

Still, you did think about those, and designed your course accordingly. My point is that at times it is not clear that this type of goals planning takes place before we plunge in and start talking about cases, clients, and possible placement settings.

Even some of the guides to program design have a tendency to dictate factors for judging placement selection which assume underlying commonalities in goals among programs. Both inhouse and externship clinics are at times thought to be synonymous with skills training. And other assumptions about common goals can lead to guidelines or standards that dictate a particular type of field experience, or suggest that some types of assignments are of greater value than others.

While there may be clear examples where particular assignments are largely inappropriate for a credited learning experience (tasks such as filing, making copies and completing largely clerical tasks), there is not one menu for all clinical programs. The selection of placement opportunities and the types of assignments within those placements must relate to the overall goals of the clinic, and to the students' individual goals. These may very well differ among programs.

\section{Marjorie:}

Absolutely. And in no way do I mean to denigrate the not-for-profit, government, or judicial externship programs. However, the opportunities available in private placement programs are another factor distinguishing externships from in-house clinics.

\section{Work and Supervision}

\section{Mary Jo:}

The planning stages of the clinic are critical, but what the students most focus on and care about is getting into the work of the office, and experiencing what it is like to be a lawyer. They are eager to jump into something that sounds exciting, important, or something that might lead to career opportunities. So in my experience, one of the challenges for us is to give them tools to help them examine and process that work experience. It's so important that they begin to analyze what they are learning, and how and why, so that they can connect this one experience to a larger learning agenda. What are some of the most important things they take away from their externships? 


\section{Working with Supervisors}

\section{Marjorie:}

While in-house clinics present clearly superior opportunities for exploring problems that arise in relationships with clients, externships are far better for exploring problems that arise in relationships with supervisors. ${ }^{82}$

SR was one of my strongest students in the fall 2009 seminar. She was always wellprepared and active in class discussions. She was struggling in her placement, however, frustrated that she was mostly assigned tasks that she had mastered in previous employment, and that didn't reflect the goals she had set for herself and shared with her supervisor. She found communication with her supervisor difficult. Her supervisor treated her no differently than, and gave her the same assignments as, she gave the several other law clerks who were receiving monetary compensation, rather than credit. The work tended to be largely indexing transcripts of depositions, a task SR had performed in a paralegal capacity in previous employment. The written work tended to be summarizing deposition testimony, also something SR had frequently done before.

Both in seminar with the aid of her classmates, and in one-on-one sessions with me, we brainstormed approaches for addressing her concerns, improving communication with her supervisor, and achieving her goals for the placement. SR, however, avoided direct discussions with her supervisor, and basically wrote her off as "a difficult person," receiving confirmation of that impression through conversations with others in the office. She resigned herself to a disappointing experience. Towards the end of the semester, and by dint of her own initiative (and encouraged to do so by the rest of us), she began working with another attorney in the office, from whom she was able to do some real research and writing, work that was more challenging, and thus more rewarding. ${ }^{83}$ But this came too late in the semester to save the overall experience from disappointment.

Unfortunately, I had completely forgotten to have mid-semester conversations with placement supervisors that semester. Had I had such a conversation with SR's supervisor, the problem that arose might well have been resolved at that juncture. At her exit meeting in late November, SR was shocked when her supervisor gave her a basically mediocre review, citing a lack of attention to detail and some other deficiencies. SR was flummoxed; she had only completed one written assignment specifically for her supervisor, one which her supervisor had never returned nor discussed with her. All of the other attorneys with whom she had worked had nothing but praise for what she produced. In addition, SR had never received anything but glowing evaluations from employers in the past and, in fact, already had a tentative offer of

\footnotetext{
${ }^{82}$ See Eyster, supra note [37] at 396-97.

${ }^{83}$ See id. at 399 (noting students' resilience in finding alternative mentors in their placements).
} 
post-graduate employment from the firm at which she had worked the previous summer. She contacted me immediately, extremely distraught, and we arranged to meet immediately. She brought with her to our meeting the deposition summary she had written, along with the "final" summary her supervisor had prepared, having compared the two and found few differences. I reviewed them and concurred with SR's assessment.

We agreed that I would wait for her supervisor's written evaluation, and then, if it reflected the same concerns, I would speak with her. The written evaluation arrived soon thereafter, and basically replicated what SR had been told. I immediately tried to contact the supervisor who, unfortunately, had just left on a two-week vacation. I left a detailed voicemail, explaining that the evaluation was inconsistent with everything I knew about the student.

When she finally contacted me several weeks later, SR's supervisor told me that SR appeared to have a chip on her shoulder. She acted as if she already knew everything. I could see how she might have this impression; SR did, in fact, know quite a lot about the work she was called upon to do in her placement. But that wasn't my impression of SR, and it certainly wasn't the impression SR intended to convey. When we met to discuss this, SR was quite reflective and not at all defensive about this, and saw it as a valuable lesson for the future. She also acknowledged that she could have been far more proactive in solving the interpersonal conflict and misunderstandings than she had been. She acknowledged her propensity for forming quick judgments that tended to impair, rather than facilitate, interpersonal problemsolving. We both agreed that while it's much easier to complain about a supervisor than to resolve any conflicts, it's not a very constructive approach. Another very valuable lesson learned.

\section{Mary Jo:}

I completely agree with your observations about the importance of helping students to learn effective communication with supervisors (and for that matter, colleagues, clients, and other attorneys). And I think it's true that these opportunities may be better in the context of an externship clinic, for a variety of reasons. First, the faculty member who is a few steps back from the interactions may have a better vantage point, certainly more objectivity that she would if she were the supervisor. I think this is one of the points in Robert Condlin's article criticizing the in-house Clinic model. ${ }^{84}$ I don't agree with the general tenor of his criticisms, but it's hard to argue that there is no difference in objectivity. ${ }^{85}$ In the externship, students will also be dealing with a different type of "accidental clinician." Many of the attorneys they work with may not

\footnotetext{
84 Robert Condlin, “Tastes Great, Less Filling”: The Law School Clinic and Political Critique, 36 J. LEGAL EDUC. 45 (1986).

85 By the way, I'm under no illusion that my performance as a supervisor in my in-house clinics is perfect. And while I do invite students to discuss ways that I can improve in my supervision, I imagine they are less than fully honest in their responses.
} 
aspire to teach (though in my experience most do in fact relish the opportunity to help law students develop into lawyers). Many have not been trained as supervisors, and have not given the role that much thought. So, that makes them just like the supervisors these students will be working with upon graduation. It's very important for the students to understand how to maximize the value of the supervision by learning strategies for coping with less than perfect supervision.

I also want to respond to your statement about checking in with the supervisor at the halfway point. Yes, that would be a great opportunity to get a situation back on course. But there are other ways to track developments in the externship. Obviously some type of regular communication between the faculty supervisor and the field office and supervisor is important. The form that this must take is dependent on a number of factors, beginning with the goals of the program. For example, if the program were designed to give all students an introduction to interviewing and counseling, the requirement that students take part in particular client interactions must be clear, and there must be agreement among the faculty director, field supervisor and student about the nature and frequency of these assignments, probably with regular check-ins to be sure the experience is taking place as planned. On the other hand, if the goals of the clinic are more general, as is the case with several of the programs that I have directed, there is no need to reach agreement on the precise tasks to be assigned to the student, and maybe less frequent checking with the supervisor. Keeping informed about the students' progress is important, and there should be set methods to accomplish that.

\section{Marjorie:}

Does this really require that faculty director and field supervisor be in direct contact? Can't the student be the intermediary between the two to insure that the goals will be met? In my seminar, students draft learning agendas or goals memos. ${ }^{86}$ They review drafts with each other in seminar, submit them to me with their weekly journals, then revise them until I am satisfied that they are ready to be shared with their supervisors. I then have them meet with their supervisors to review the goals. Many of them resist at first. ${ }^{87}$ Most lose their reluctance when they hear from classmates how well the experience went. If goals cannot be achieved through their placement, supervisors will let them know. Often supervisors find creative ways to help them achieve their goals, perhaps by working temporarily in other divisions or under

\footnotetext{
${ }^{86}$ See OWL, supra note [], ch. 2.

${ }^{87}$ Students seem to fear that their supervisor will find the exercise of reviewing their goals a waste of time, either because they have previously discussed them or because the supervisor is too busy to spend time on what they may perceive as an academic exercise. It is true that invariably there will be one or two supervisors-usually solo practitioners - who are so busy that finding time to do this does appear to be a burden. For those, I suggest the student email asking when would be a convenient time to meet, and blame the need to do so on me. For other students, they are usually won over when one or more classmates who do meet with their supervisor to discuss their goals report how well the meeting went. Supervisors generally welcome the opportunity to focus on exactly what the student hopes to achieve or do, and to have a frank conversation about what's feasible.
} 
other attorneys. This then becomes a "contract" for us to monitor how well or not students are able to achieve their goals during the placement.

I also helped revise the agreement that the supervisor and student both sign, specifically including details with regards to expectations for assignment clarification and effective feedback. But I am under no illusions that just because we send it to the supervisors in writing, and they sign it, that they have, in fact, read and reflected on our requirements!

\section{Mary Jo:}

Marjorie, I think we are really saying the same thing. You describe a process by which the students communicate with the supervisor, but also with you, about what they are communicating. It works in your program because you don't have precise "skills training" goals that might require more ongoing direct contact. I also put a lot of the onus for communication on the students, although I do have initial contacts with the supervisors, end of term contacts, and sometimes more, depending on circumstances. When I refer to "introduction to the skills necessary to develop and excel as a professional," (one of my goals listed above), I am not necessarily referring to what is often thought of as "skills training." I am referring to something that is more general, although developing specific skills may be part of the student's individual learning agenda.

\section{Supervision and Self-Correction}

\section{Mary Jo:}

Professionals are required to take responsibility for their work, their knowledge, their performance and their ongoing development. Many of the students we teach will enter the profession without a full comprehension of what this all entails. Law school curriculums are largely directed from top down. The first year in most schools is entirely dictated by course requirements. After that, there are usually many electives, but there is also a culture (possibly overly influenced by bar exams) that results in a predictable pattern of student choice. Thus, many courses that are not required will be heavily enrolled because students understand that they are expected or necessary, regardless of the individual student's interest in the subject matter. While all of this may in fact result in students choosing appropriate courses, what is missing is development of the skills needed to guide choice going forward as a professional. Although we do want our students to be governed by accepted norms and the dominant culture - at least up to a point - as lawyers we expect them to know how to evaluate situations, consider goals and impediments to those goals, and select alternatives designed to optimize chances of success. I think this is the essence of the MacCrate Report's $4^{\text {th }}$ Fundamental Value: Professional SelfDevelopment. $^{88}$

\footnotetext{
${ }^{88}$ See MACCRATE REPORT, supra note () at $218-21$.
} 
I, too, have structured the externship course requirements to try to introduce the goal setting and assessment skills that students will need as they move forward into the role of professional. ${ }^{89}$ Because they are choosing among a variety of possible placements settings, and they will be working not with a faculty member devoted to teaching, but with a lawyer dedicated to serving one or more clients, students in externship courses have fundamental responsibility for designing their own learning experience. I view this not as a shortcoming in the externship clinic model, but as a great opportunity. I do not insist that field supervisors be officially trained as clinical supervisors. Although I do provide guidelines in the form of a field supervisor manual (which has been adopted by other programs both within my school and in other schools), I, too, know that there is no guaranty that each of the supervisors has read and fully adopted the suggestions provided. ${ }^{90}$ Consequently, although we require some fundamental acceptance of the program requirements, there are many supervisors, with a range of practices and abilities, not all of them optimal for an individual student's needs. ${ }^{91}$ The components of the course that are devised to alert students to the goal setting and assessment processes are as follows. At the outset, when they have selected a possible placement setting, they are required to articulate what their goals are for that internship experience, and how they expect to achieve those goals. They are also asked whether they have reached an understanding with their supervisor about the nature of their assignments and opportunities to work toward their desired objectives. In my orientation class with my internship students I discuss with them the differences in the externship experience and both other clinical experiences and job experiences. My hope is that they will begin to sense that there are differences in all three settings. First, the job setting should be distinguished from the internship, as there may be no learning goals or career development goals involved in a pure work experience [although as professionals they should probably include such goals even in a work experience]. Second, the in-house clinical experience is different because the faculty member who is selecting cases and supervising the students' work is presumably focused primarily on the student learning experience, rather than solely on providing effective client service. And third, in the in-house clinic there is likely to be much greater control over, and hence predictability about, the types of cases and assignments the students will receive. ${ }^{92}$

Throughout the externship course students are required to keep ongoing journals that discuss their work assignments, not simply in terms of the tasks completed, but more importantly in terms of what they are learning from the work. The journal is intended to give them a regular (daily) opportunity to step back a few paces from the day to day tasks and to consolidate their thoughts about the enterprise. I invite them to comment on any aspects of law practice that are

\footnotetext{
${ }^{89}$ See supra, text at notes [where MAS discusses same].

${ }_{91}^{90}$ See supra, text at notes [where MAS discusses same].

91 Although I don't require my in-house or externship students to take a Myers-Briggs personality assessment, I do strongly encourage them to do so (using an online, truncated version that takes about 10 minutes to complete. The test can be accessed at http://www.humanmetrics.com/cgi-win/JTypes2.asp . I spend some time in class talking about type, and how it might impact the student-supervisor relationship. In my own supervision I try to be sensitive to these issues as well, but of course it is easier to be objective about a relationship that one is not part of.

92 As noted earlier, these are some of the great values of the in-house clinic. Students are in a learning environment that was presumably designed for learning, and that is closely controlled.
} 
impacted - professional responsibility, substantive law, effective legal advocacy or any others. These journals are read by the seminar professors, and may prompt class sessions devoted to topics that have arisen in the students' journals. ${ }^{93}$ This interchange of information from student to professor, as well as the student's own personal reflection on his/her experience, is a critical piece of the experiential learning. It provides the opportunity for self correction, or for correction by the seminar professor, if there is something that needs discussion or adjustment. At times the student's commentary may be designed to gently solicit the professor's view points. At other times, the student may be unaware that there is anything that requires consultation. In either case, both affirmation and correction are important aspects of the experience, and are greatly enhanced through the journal exchange.

Midway through the course, students in my externships are required to respond to specific questions designed to allow them (and me) to assess how their learning experience is progressing. I ask them to revisit the goals they articulated at the outset, and to consider whether, and how well, they think they are achieving those goals. I also prompt them to consider whether they can identify modified, or even entirely different, goals that they might achieve. By taking stock of the experience at the halfway point, students can evaluate what steps they need to take to reach a successful completion of the internship. There are many possibilities, but the most common are: change the type of assignments, complete a stalled project, and discuss work and careers with the supervisor.

A very common shift at the mid-term is a change in the type of assignment. Often students have reached a point of confidence in handling a particular type of work, and both they and their supervisor are comfortable with their ability. The sense of "expertise" in working on a particular type of motion or contract is welcome by the student, who may not be eager to move into an unfamiliar area. My gentle prompting is to seek something new that they have not yet learned, something that they know is important in that field of work. If time were not an issue, this point would likely come about naturally. However, the space of one semester, especially in a lower credit internship, does not allow for the natural pace of full time practice. The term is halfway over often before the students are fully settled in, and they need to be reminded of the limited time they have. Assuming that the externship supervisor has not structured the experience specifically to provide a rotation among divisions or supervisors, it is necessary to alert everyone that it's time to "change partners."

Another type of rhythm that might come about naturally in full time practice relates to the completion of large and/or long-term assignments. Often students are engaged in a long-term project as well as more limited assignments with quick turnaround deadlines. The mid-term check-in may serve to shift them into picking up the neglected long range assignment. Ideally

\footnotetext{
${ }^{93}$ My practice is to treat all journal information as confidential unless the student has given full consent to have their reflections discussed as part of the seminar. However, if there are general questions or themes that are raised in journals, I will sometimes bring them up without attributing them to an individual student. I never share journal comments with supervisors unless the student and I agree.
} 
one of the remaining lessons that derives from this process is the need to monitor one's progress, and to set deadlines for projects, even without external deadlines being imposed.

At the middle point in the term, or at least at some time before the end of the term, students who have not yet had a thorough-going discussion with their supervisors are urged to do so. Primarily the purpose is to give them a chance to get a more global assessment of their work, rather than the individual assignment feedback they have been getting throughout. It is critical that the student be aware if there are problems that s/he needs to address, in terms of work habits and assignments. Students also relish the opportunity to discuss career goals and paths with the attorneys who are in positions that these students aspire to. Supervisors can share information about substantive learning as well as practical learning (for example, courses in trial practice or other clinical and internship courses) that will help the student complete her legal training. Following these midterm discussions with supervisors, many students report a re-energized internship, often with increased responsibility and new assignments.

The final requirement is an essay in which the students address similar questions about their goals, their assessment about achievement, and new goals that may have grown from the internship experience. This final essay builds on the preceding reports, but serves a slightly different purpose. Not only is the student reporting on what s/he achieved, but also on how well the internship, including the supervisory relationship, met his/her needs. Also, s/he is looking ahead to further professional growth.

Here are some examples of how these pieces fit together for my students.

AS: I wanted to spend this semester gaining a better understanding of how [a judge] goes about the process of judicial reasoning and coming to conclusions when dealing with difficulty issues. Admittedly, this is a more abstract goal than many I have, but it is also one that I think is very valuable for all lawyers. It is also a goal that cannot be achieved solely by writing and researching. ... The trial afforded me the opportunity to sit with the clerks and be privy to all side bar arguments. It also allowed me to observe how the judge adjudicated the many tangential disputes that arose from the case.

\section{And EM:}

Although I am not sure of what my ultimate career objective is, I am very interested in corporate and securities law. This internship has helped me in preparation for a career in that field in more ways than I had anticipated. . . . I believe that this internship has made me more prepared to be an attorney in the corporate field. Beyond improving my writing and research abilities, the internship gave me insight into some of the legal issues corporate lawyers work with.

JO found an opportunity to explore a new area of interest:

When I entered [the internship] I barely knew the difference between a debtor and a creditor. I had no idea what a secured claim was, or how an estate functioned. I have learned this, as well as how to navigate my way through the Bankruptcy Code and useful secondary sources (like Collier on Bankruptcy).... This internship has 
definitely helped guide my path for the future. As far as learning objectives, I want to build on my newly formed basis in bankruptcy law by taking Debtors' and Creditors' Rights and then Business Reorganizations.

The above tools, the goals statement, weekly journals, mid-term assessment and final essay, serve essentially the same set of pedagogical goals. They are aimed at helping the student figure out how to map a course toward a desired end, and to continuously evaluate the progress s/he is making. This set of skills will enable the student to move forward as a professional as s/he learns to take charge of his/her own path.

\section{Marjorie:}

I've already discussed my use of goals statements or learning agendas, and we'll get to selfassessment in a bit, but I would like to talk about my use of journals. ${ }^{94}$ The great thing about journals, even though the students might require some convincing, is that they serve several complementary purposes.

Journals are also a wonderful opportunity for students to work on their basic writing skills. Many-perhaps most-of our students have significant deficiencies in this regard. Given how important good writing is to good lawyering, I see it as my responsibility - not solely mine, of course, but neither is it solely the Legal Writing teacher's responsibility-to help my students improve their writing. I spend a good deal of time correcting or highlighting my students' grammatical and spelling errors. I strongly recommend that those students whose problems are greater than average seek assistance from our Writing Center, stressing that they should take advantage of this "free" support while it's still available to them. Virtually all of them who start out with writing deficiencies improve substantially over the course of the semester.

In terms of supervision and self-correction, journals can be a tool for the student, and the faculty supervisor who is reading them, to focus on areas that are strong and on areas that might need adjustment. So, while we can discuss journals as an assessment tool, they are also related to helping the student achieve the goals s/he has identified, and one of the primary goals that I have identified - assisting the student in becoming a reflective practitioner.

I find guided questions to be particularly helpful in this regard, as they require the students to focus specifically on aspects of their seminar and placement experiences that they might otherwise not think about in any depth. ${ }^{95}$ Here are some examples:

- Journal about your experiences at your placement this week. If this is your first journal since you started, what were your initial impressions of the office? How well did your supervisor (or other personnel) explain office procedures,

\footnotetext{
${ }^{94}$ See discussion, infra, text at notes []-[].

${ }^{95}$ In addition, I always give the students the opportunity to write anything else they would like to.
} 
expectations, etc? For all of you who have started, what surprised you? What concerned you? ${ }^{96}$

- As you read Professor Daicoff's chapter, consider the personal inventories you completed in our first class .... Do you share mostly "typical" or "atypical" law student/attorney characteristics and preferences? Journal_about how your characteristics and preferences might or might not be reflected in the work you will be doing, or the challenges you may face, in your externship. ${ }^{97}$

- Eulogy Exercise: At the end of today's class, I asked you to write what you would like to have said at your funeral. The first would be what a loved one, spouse, or life partner would say about you. The second, what someone from a community that you were a part of would say about you. And the third would be what a lawyer or judge for whom you had tremendous respect would say about you. ${ }^{98}$

Please journal about what this exercise revealed about your own intrinsic and extrinsic values (see Krieger handout).

- Reflect on something we discussed in class yesterday, either during rounds, during our discussion of dealing with clients and law as a healing profession, or our discussion of the Schiltz article.

Perhaps the most useful of all are assignments that require them to review previous journals, such as "Look back over your prior journal entries and my comments. Write a reaction to or reflection on something that either you or I (or both of us) wrote." Or that asks them to take stock in where they are in achieving their goals, such as "Review your goals memo or learning agenda. Discuss what you have been able to accomplish in your placement, and what you have not yet been able to accomplish. What steps do you plan to take with respect to the latter?"

Mary Jo:

What you have just described sounds almost exactly like the mid-term assignment I give them, which I mentioned earlier. That is exactly the point of that exercise - to help them to take stock, self-correct and take steps to reach their goals.

\section{Assuming the Professional Role}

\section{Mary Jo:}

An additional aspect of the work/supervision topic I would like to discuss is another of the goals that I have enumerated - the opportunity to test skills and knowledge as applied, to gain a fuller appreciation of the nuances of substantive and procedural law. The relationship between the student and the supervisor is part of this larger context - the student's performance in the role

\footnotetext{
${ }^{96}$ [check/cite source]

${ }^{97}$ See supra text at note [Daicoff's learning inventory].

${ }^{98}$ See supra text at note [Krieger exercise].
} 
of lawyer. Helping students achieve success in this relationship is extremely important to their overall sense of success.

One of the most common emotions shared by students entering an externship placement is apprehension about their ability to perform the work required in the professional role. One of the most common revelations students experience through their internships is that they are indeed able to connect the dots of theory in the reality of practice. In practice, students are surprised that they have indeed achieved competence in understanding how to research, analyze and apply the law. ${ }^{99}$ Often they need to adapt their approaches to the more concrete context of practice with real clients and real problems, shedding the all too general writing styles they may have mastered for exam taking. Still, they are able to make that adjustment, and to draw confidently on the skills in analysis and writing that they have started to develop in the classroom. This opportunity is key in helping students to appreciate the value and importance of what they are able to learn in the classroom setting, and also in helping them to determine what additional knowledge they may need to cultivate through their studies. A very important lesson for many students is discovering how rules of evidence and procedure are so critical to the outcome of their cases (rather than simply dry and monotonous rules inflicted on them by law faculties.

Adult learning theory in general supports the notion that contextual learning is important. ${ }^{100}$ For many learners, understanding the utility and application of the material under study contributes to the commitment to learn. Or, put another way, adult learners may insist on understanding why they need to know something before they will fully engage themselves in the process of learning. ${ }^{101}$

Here's an example of the way this process worked for one student:

AB: To begin the investigation, I would call the [party] to set up a time for him or her to come to the office. . . Taking affidavits is one skill that I practiced a lot at this internship, and it is a valuable skill. I would have to prepare to take the affidavit by studying the area of law . . to determine what were the elements of that charge. Then I would sit down with the individual, and try to zero in on whether those elements had been met. ... [A]ll the experience I gained in taking affidavits is something I think I will definitely take with me. It is not a skill I have learned about in any context anywhere else in law school, but it is an important part of lawyering and a slippery skill to learn. I think from the practice I gained in taking affidavits this semester, I come away a much more capable lawyer with respect to working with clients and applying facts to law, as it were, to narrow down stories to their most important elements while also learning the whole story.

And in a similar vein:

\footnotetext{
${ }^{99}$ No offense to the first year faculty, but they seem not fully to trust that we are teaching what they need to know. ${ }^{100}$ See, SCHWARTZ ET AL., supra note [8] at 8-9 (mentioning that the same probably pertains to all learning).

101 But see Linda Morton, Janet Weinstein \& Mark Weinstein, Not Quite Grown Up: The Difficulty of Applying An adult Education Model to Legal Externs, 5 CLIN. L. REV. 469, 471 -82 (1999) (discussing the development and application of adult learning theory, followed by their observations about the shortcomings as applied to law student externship teaching).
} 
GB: I learned much about the substantive law regarding these issues but more importantly I developed an appreciation for the quantity and subtlety of legal issues that arise throughout the life of an investigation."

It might be argued that the same opportunity can be provided by an in-house clinic. I have several responses to that. The first is, yes, I agree, assuming that the student will be able to enroll in a clinic that s/he perceives to be in an area of practice that is in line with his/her career goals. The second response, relates to the first. Our in-house clinics offerings are necessarily limited. We may have a large variety of clinical opportunities offered within the law school, but the breadth of subject matter will not come close to replicating the variety in the legal world. Building on this, my third response is that it is unrealistic to suggest that law schools can actually provide either the range or the number of clinical offerings to satisfy the needs of all of our students. Regardless of one's commitment to clinical education, the cost of in-house clinical courses prohibits any guaranty that all students will have those opportunities, as discussed earlier. $^{102}$

Finally, the opportunity to engage in a clinical experience outside the law school, with lawyers and colleagues who are not focused solely on educating the student, is more of a test of ability for most students than the in-house clinic. Many students are aware that there is a distinction between the slow, thoughtful and controlled practices of in-house programs, and the difference in the oftentimes chaotic pace and direction of real world lawyering. Of course it is not uncommon for an individual student to take part at some point in both types of clinic.

Here is an insight from HM:

From this externship I was able to identify areas of strengths and weaknesses in my lawyering abilities as well. My biggest strength is my writing ability. . . A weakness that I was able to overcome during the course of my externship was my ability to balance the need to finish something quickly while also ensuring my work product was precise. At times it was necessary to finish something quickly by a deadline but that meant I would have less time to proofread my work and make sure it was accurate. I had to learn to balance both demands, and I feel I was able to do so by the end of the semester. Achieving this balance will greatly aid me in my future work."

\section{Optimizing Sub-optimal Experiences}

Mary Jo:

A fact that we should acknowledge, and have already, to some extent, alluded to, is that sometimes students do have disappointing experiences in their internships. ${ }^{103}$ This can be for a variety of reasons, some of them already discussed. The work might be different than what they expected, cases may settle, opportunities change. We talked about resilience ${ }^{104}$ and learning to

\footnotetext{
${ }^{102}$ See supra text at notes [].

${ }^{103}$ See supra text at notes []. See also Eyster, supra note [] at 399-400 (discussing value of disappointing externship experiences).

${ }^{104}$ See supra text at notes [].
} 
manage the supervisory relationship. ${ }^{105}$ And we talked about the great value of learning from experience what types of life choices might be inherent in a particular type of practice. ${ }^{106}$ Are there other points we should consider about using the "negative" experiences to reach a "positive" outcome?

\section{Working with Difficult People}

\section{Marjorie:}

SR's story ${ }^{107}$ is also an example of something some subset of my students will encounter in their placements: the challenge of working with difficult people. ${ }^{108}$ Some of them rise to the challenge, and grow accordingly. Others don't. The reality is that many of them will have to work with difficult people at some time in the future-be they clients, opponents, or supervisors. Learning how to do so will serve them well. Failing to do so might even cost them their license.

We seldom have controlled experiments, and my sampling is rather small, but I have supervised two women who worked for a particularly "challenging" male attorney ${ }^{109}$ in a Long Island satellite office of a large New York City firm, with decidedly different experiences. This attorney's reputation preceded him; I had heard that a female student the year previous to when Aretha externed with him had, at first, found him difficult, but was able to adjust to his style and demands and had had an extremely rewarding externship experience under his tutelage. Aretha, too, found him harshly judgmental and her early journals reflected her insecurity about her work and his judgments about her abilities. She learned an incredible amount, not only about the substantive law she wished to learn in her placement, but also about how not to treat law students. She found his emotional competence to be decidedly lacking. However, her overall assessment of the experience was quite positive, and ultimately her placement supervisor practically begged her to continue working for him for the following semester. ${ }^{110}$

Greta, a talented and passionate law student whom I had had as a student twice before in other courses, was placed with the same supervisor a couple of years later. His style had not changed. She had never before had a supervisor with such an abrasive and difficult personality, and, despite my efforts to help her address the problems she encountered with him, the two of

\footnotetext{
${ }^{105}$ See supra text at notes [].

106 See supra text at notes [].

${ }^{107}$ See supra, text at notes [-].

${ }_{108}$ See Eyster, supra note [37] at 398 ,who is far less judgmental, discussing incompatible styles of supervision.

${ }^{109}$ As Touro had not placed any men with him, it would be rash to speculate as to how gender might have affected his relationship with the externs.

110 She declined because of other obligations (such as law review).
} 
them were never able to form a satisfactory working relationship. Ultimately, circumstances caused her to change placements mid-semester. ${ }^{111}$

\section{Collateral Benefits: Training the Supervisors to be Self-Reflective Practitioners}

\section{Marjorie:}

We spend a great deal of time in seminar discussing assignment clarification and effective feedback, first as a discussion topic in and of itself, ${ }^{112}$ and then as it often arises during rounds or in response to journal entries when students are having problems with one or both. One incredibly creative idea was offered by a student to help resolve Greta's problem in receiving little direction from her supervisor, and then having him tell her what she did was not what he had asked for. After the supervisor has given assignment Greta would shoot an email to the supervisor summarizing her understanding of the assignment, and requesting that the supervisor either confirm or correct her understanding. This is a technique I have since recommended to other students, and, as well, adopted with my research assistants, to great advantage.

If I have found it useful, I can only assume that some supervisors have as well, and that they have reflected on the ways that they might improve communication with those who do work with them. ${ }^{113}$

I imagine that the entire experience of working with students who are self-reflective, who have thought through their goals and discussed them with their supervisors, provides an occasion for practicing lawyers to pause and reflect on how they do what they do-and why they do it. ${ }^{114}$ If they weren't called upon to explain such things to the students, many might find little if any time to be self-reflective. This is a collateral benefit for the lawyers who agree to be supervisors, which in-house clinics are unable to provide. I would like to think this contributes to the overall quality of the bar, or at least the quality of the lawyers who serve as placement supervisors.

\footnotetext{
111 [Add more details if I get permission]

112 See OWL, supra note [], ch. 3.

113 See Eyster, supra note [37] at 392 (discussing multiple agenda in inviting supervisors as guest lecturers).

${ }^{114}$ See Maranville, supra note [] at 135 ("I would argue that too often unsupervised students simply pick up bad habits. Good role models can perform a task well, but may lack the time or skills to supervise well by explaining what they are doing and why or ask the student to think through these questions.").
} 


\section{Self-Assessment}

\section{Mary Jo:}

Let's talk about how we assess what we are teaching, or what we are helping them to learn. How do we know if they are getting value from the experience?

I already described in great detail what types of reports and self-assessment the students do throughout the internship, as part of setting and tracking their learning goals, and ultimately, these same tools become part of the students' final self-assessment. My students are required to complete an essay at the end of the term to address questions about the value of the learning experience and also future learning objectives. To complete this assessment, they are first directed to consider the goals that they identified at the outset, and to evaluate whether, and how well, they achieved their goals. ${ }^{115}$ Essentially, this process is rather like the evaluation process I use for my in-house students.

\section{Marjorie:}

Students are so used to being evaluated by others that many are taken aback when asked to assess their own performance. It's unfortunate that we ultimately have to reduce an assessment of what they have accomplished in their placement and the seminar to a grade, but the most important part of the process involves the students' reflections on what they have accomplished, and what they still need to work on, to become the lawyers they and we hope they will be.

Mary Jo, I think your mid-semester assessment is a wonderful idea, and I intend to implement it forthwith! ${ }^{116}$ What I have been doing at the end of the semester is similar to your approach. My final journal assignment is as follows:

As discussed, your final journal assignment is based on the topics raised in OWL Chapter 20, ${ }^{117}$ with emphasis on the following:

- Evaluate how well you met your set goals and objectives (see pp. 451-52)

- Evaluate your time records: how you spent your time and what you learned about how you manage your time (pp. 453)

- Based on your review of your journal entries over the course of the semester, reflect on insights you have acquired over the course of the semester. (pp. 453-54)

\footnotetext{
115 In addition, each student's supervisor completes an evaluation of the student's work, which asks them to comment on strengths, weaknesses, areas for improvement, and also to rate the student's performance in specified skill areas.

${ }^{116}$ Mary Jo: It sounds to me like you are already doing something quite like it, as I said earlier. Maybe the difference is one of timing, but at any point during the semester students can be urged to take stock of their learning experience and take the steps necessary to self-correct.

${ }^{117}$ OWL, supra note [] at 451-58.
} 
- What have you learned about learning from experience? (p. 454)

- Discuss your goals, your learning agenda, for the future. What are your plans for continuing to develop the knowledge, skills and values you have identified as important for your future career? If possible, set some measurable goals for the next few months, year, or beyond.

- Anything else you would like to share with me in this, your final journal entry!

In addition, I ask them to carefully review the course requirements in preparation for a final meeting with me in which I will ask them to evaluate how well they met each requirement. ${ }^{118}$ । generally ask them to tell me how well they think they met the course requirements before I offer my feedback. Although most of them are willing and able to discuss what they were able to accomplish in their placements, most have more difficulty in discussing their performance in the seminar, likely because of the reality that I am the one who will dole out their ultimate grade. Some of them prepare meticulously, as they would for oral argument. Others don't prepare at all. Most have clearly given some thought to preparing for the meeting, but there tends to be an understandable reluctance to own up to their deficiencies. I endeavor to keep the focus positive, both by emphasizing what they have accomplished over the course of the semester, as well as encouraging them going forward to work on any areas that need further development to enable them to become the best lawyers they can be.

The self-reflection necessary for this kind of self-evaluation is an example of the habit which I hope they are now developing, all part of what Learning from Practice refers to as the Experiential Learning cycle: planning, doing, reflecting, and integrating, ${ }^{119}$ a process that the reflective student and lawyer must internalize.

Mary Jo:

One thing that I find really interesting about this topic of self-assessment is how it relates back to the earlier topic of goals. ${ }^{120}$ What I described under my general goal of "introduction to the skills necessary to develop and excel as a professional" were techniques in the form of self-

118 The assignment is as follows:

\section{Self-Evaluation}

For better or for worse, the task falls to me to assign you a grade for the seminar and externship. I will be receiving feedback from your supervisors which will be one of several components of that grade. The other components were set forth in the Course Information and Requirements memo in the original packet that I shared with you at our first class together (and that is posted as well under Course Materials on TWEN). Please review that memo. Before I assign you a grade, I will be meeting with each of you (be sure to sign up on the TWEN sign-up sheet). I will give you the opportunity to self-evaluate, given the criteria set forth in Course Requirements. If you like, you may supplement that meeting with a written self-evaluation (or just rely on your final journal).

The course requirements referred to include: professionalism, journals (quality of writing and reflectiveness), class participation, short in-class presentations and keeping time sheets.

${ }^{119}$ OWL, supra note [] at 3-4.

${ }^{120}$ See discussion, supra, note[] and accompanying text. 
assessment tools. Essentially they have a dual, but certainly very closely related purpose. Students are not only providing themselves and me with information about how they are doing, but they are hopefully learning techniques that will be important to their development as professionals. We have to learn to evaluate our own progress, and to set goals for ongoing development as professionals.

\section{Part III}

\section{Clinical Program Design for the $21^{\text {st }}$ Century}

Mary Jo:

Well, Marjorie, where are we now? Externships are not the same as in-house clinics, at least not in all respects. They certainly share some of the great benefits of placing students in the office, in the role of practicing lawyer. The supervision is probably the primary point of departure, since the externship supervisor may be more focused on practice, and less focused than the in-house faculty supervisor on the student's learning experience. Do we have to decide which is best? How do we choose?

\section{Marjorie:}

Might you rethink this question? Are you wedded to keeping the reader in suspense as to our conclusion that they are complementary, not in competition? I guess you know my preference!

\section{Mary Jo:}

Yes, I do think I know your thoughts on this topic, and of course, by now, you must know mine. I have been teaching in-house clinics for 26 years, and externship clinics for close to 20 years. I am hopeful that many clinical teachers have come to see the value in both. You spoke earlier of the externship as a type of capstone experience. ${ }^{121}$ My comment on that is based not simply on pedagogy, but also on economic realities. In order for the externship to be a capstone available to all, we would have to figure out how to make the in-house clinic experience also available to all, or at least to all who want that opportunity. In a school with class enrollments over 300 (such as mine), I do not think that is going to happen. So, while I agree with the concept, I think we also need to consider what is necessary to make an externship clinic a legitimate and rich learning experience as an alternative to the in-house clinic.

\footnotetext{
${ }^{121}$ See, supra, text at [intro].
} 


\section{Marjorie:}

What I spoke of earlier is, as I acknowledged, unobtainable in legal education today. In fact, even resources currently devoted to clinical programs cannot be taken for granted going forward. Ideally, students would first learn the knowledge, skills and values necessary for good lawyering in the relatively controlled environment of the in-house clinic, under the close supervision of an experienced clinical teacher, preceded, perhaps, by simulation-based skills courses. Then, once the students have the ability to recognize "best practices," they would have the tools, hopefully, to critically and reflectively examine what they experience in "the real world" of their externship placement.

Some schools have clearly made more progress towards such ends than others, ${ }^{122}$ but resources drive pedagogy more often than I would care to acknowledge. ${ }^{123}$ So, yes, in addition to all of the other ways we have discussed that externships add value to the student's development into an independent lawyer, there is also the reality that for most students at most schools, in-house clinics will not be a realistic option.

\section{Conclusion}

\section{Mary Jo:}

Marjorie, I'm really so glad that you invited me to have this conversation, and that we somehow managed (despite some scheduling challenges) to make it happen. I want to take a few steps back to look at the bigger picture - the one I think you had in mind when we first talked about this. Externship clinics have a place in the curriculum that should be recognized, respected and valued. In-house clinics are wonderful opportunities for students to experience practice in a more measured and controlled environment than might be possible in a field placement. I teach in both types of clinics, and I think I do understand the values of both. Apart from the economic reality - that law schools are not fiscally structured to offer all of their students an in-house clinical experience, it is important to consider the pedagogical reality as well: Externships can offer a different perspective for many students and can provide a learning experience that is as valuable as the in-house setting. We should be thinking more about ways to maximize the value of both of these models, and others. Looking back at several decades of scholarship on the goals, structure and value of externship clinics, I am both impressed and frankly a bit discouraged. Why are some of us still stuck in a debate about the legitimacy of this type of learning, rather

\footnotetext{
${ }^{122}$ See, e.g., Stephen Ellmann, The Clinical Year, 53 N.Y.L.S. L. REV. 877 (2008/09) (describing planned pilot project for year-long capstone clinical experience). [cite to additional schools, e.g. CUNY, Drexel, others?]

${ }_{123}$ When, anticipating our move to a state-of-the-art facility in Central Islip from a renovated WPA junior high school in Huntington, a group of us from the Touro faculty originally envisioned our transformed curriculum, we envisioned a capstone clinical third year. [cite to Curriculum report]. However, once we moved to implement our vision, the realities and impracticalities of the resources required for such a possibility forced us to scale down our plans considerably. The third year of our curriculum is still a work in process.
} 
than focused more on ways to make clinical legal education available, valuable and fully integrated into the curriculum?

\section{Marjorie:}

Mary Jo, I now invite you to reconsider being discouraged, although I acknowledge that my seeing the proverbial glass as half full may be a product of my limited experience. That we have had this conversation, and that we get to share it with our colleagues in both in-house and outhouse clinics (pun intended) bodes well for the future, I believe. We all must band together to insure that each aspect of experiential learning - simulations, externships and in-house clinicsare independently valued for what they have to offer. ${ }^{124}$ And to add one last bromide, there's a lot more that unites us than divides us in this quest.

${ }^{124}$ See Clinical Legal Education's (CLEA) COMments on Outcome Measures to the ABA's Standards REVIEW COMMITTEE (July 1, 2010) (criticizing proposed weakening of professional skills requirement by requiring only a single skills "learning experience"). 